\title{
A Web-based Spatial Decision Support System of Wastewater Surveillance for COVID-19 Monitoring: A Case Study of a University Campus
}

\author{
Wenwu Tang a, , ${ }^{a *}$, Tianyang Chen ${ }^{\mathrm{a}, \mathrm{b}}$, Zachery Slocum ${ }^{\mathrm{a}, \mathrm{b}}$, Yu Lan ${ }^{\mathrm{a}, \mathrm{b}}$, Eric Delmelle ${ }^{\mathrm{a}, \mathrm{b}, \mathrm{c}}$, Don Chen ${ }^{\mathrm{d}}$, \\ Neha Mittal ${ }^{\mathrm{e}}$, Jacelyn Rice-Boayue ${ }^{\mathrm{d}}$, Tarini Shukla ${ }^{\mathrm{b}, \mathrm{f}}$, Sophia Lin $^{\mathrm{f}, \mathrm{g}}$, Srinivas Akella ${ }^{\mathrm{h}}$, Jessica \\ Schlueter ${ }^{\mathrm{e}}$, Mariya Munir ${ }^{\mathrm{g}}$, Cynthia Gibas ${ }^{\mathrm{e}}$
}

a Department of Geography and Earth Sciences, University of North Carolina at Charlotte, Charlotte, NC 28223 USA

${ }^{\mathrm{b}}$ Center for Applied Geographic Information Science, University of North Carolina at Charlotte, Charlotte, NC 28223 USA

${ }^{\mathrm{c}}$ Department of Geographical and Historical Studies, University of Eastern Finland, Joensuu, Finland

${ }^{\mathrm{d}}$ Department of Engineering Technology and Construction Management, University of North Carolina at Charlotte, Charlotte, NC 28223 USA

e Department of Bioinformatics and Genomics, University of North Carolina at Charlotte, Charlotte, NC 28223 USA

${ }_{\mathrm{f}}^{\mathrm{f}}$ Infrastructure and Environmental System Program, University of North Carolina at Charlotte, Charlotte, NC 28223 USA

g Department of Civil \& Environmental Engineering, University of North Carolina at Charlotte, Charlotte, NC 28223 USA

${ }^{\mathrm{h}}$ Department of Computer Science, University of North Carolina at Charlotte, Charlotte, NC 28223 USA

*Corresponding author, Email: WenwuTang@uncc.edu, Phone: 1-704-687-5988 
medRxiv preprint doi: https://doi.org/10.1101/2021.12.29.21268516; this version posted January 1, 2022. The copyright holder for this preprint (which was not certified by peer review) is the author/funder, who has granted medRxiv a license to display the preprint in perpetuity.

It is made available under a CC-BY-NC-ND 4.0 International license .

\section{Abstract}

27 The ongoing COVID-19 pandemic has produced substantial impacts on our society. Wastewater

28 surveillance has increasingly been introduced to support the monitoring, and thus mitigation, of

29 COVID-19 outbreaks and transmission. Monitoring of buildings and sub-sewershed areas via a wastewater surveillance approach has been a cost-effective strategy for mass testing of residents in congregate living situations such as universities. A series of spatial and spatiotemporal data are involved with wastewater surveillance, and these data must be interpreted and integrated with other information to better serve as guidance on response to a positive wastewater signal. The management and analysis of these data poses a significant challenge, in particular, for the need of supporting timely decision making. In this study, we present a web-based spatial decision support system framework to address this challenge. Our study area is the main campus of the

37 University of North Carolina at Charlotte. We develop a spatiotemporal data model that

38 facilitates the management of space-time data related to wastewater surveillance. We use spatiotemporal analysis and modeling to discover spatio-temporal patterns of COVID-19 virus abundance at wastewater collection sites that may not be readily apparent in wastewater data as they are routinely collected. Web-based GIS dashboards are implemented to support the

42 automatic update and sharing of wastewater testing results. Our web-based SDSS framework 43 enables the efficient and automated management, analytics, and sharing of spatiotemporal data of

44 wastewater testing results for our study area. This framework provides substantial support for

45 informing critical decisions or guidelines for the prevention of COVID-19 outbreak and the mitigation of virus transmission on campus.

47 Keywords: Wastewater surveillance, spatial decision support systems, COVID-19, Web GIS 
medRxiv preprint doi: https://doi.org/10.1101/2021.12.29.21268516; this version posted January 1, 2022. The copyright holder for this preprint (which was not certified by peer review) is the author/funder, who has granted medRxiv a license to display the preprint in perpetuity.

It is made available under a CC-BY-NC-ND 4.0 International license .

\section{Introduction}

49

50

51

52

53

54

55

56

57

The COVID-19 pandemic has fueled a renewed interest in wastewater-based epidemiology.

Wastewater testing for traces of viral and bacterial pathogens has been used for decades to track and manage outbreaks of infectious disease (Prado et al., 2012; Tambini et al., 1993). Early reports in mid-2020 demonstrated that wastewater concentrations of SARS-CoV-2 could serve as a leading indicator for cases detected by clinical testing within city sewersheds (Ahmed et al., 2021; Peccia et al., 2020), with collection of samples from wastewater treatment plant influent providing coverage of entire cities or large neighborhoods. The practical application of monitoring at city scale is primarily to detect infection trends in communities, which has been especially useful in the case of COVID-19, both because COVID-19 infections may be asymptomatic for several days prior to detection of cases by testing, and because especially in the early months of the pandemic, testing capacity lagged behind the rapid spread of the disease. In such scenarios, wastewater testing can serve as a leading indicator of the increase of disease incidence in an urban area. There has also been an increasing interest in monitoring in neighborhood or smaller scale areas for the presence of the SARS-CoV-2 virus in wastewater, because such small-scale monitoring can provide evidence to support targeted public health interventions including distribution of masks or selection of populations for increased testing (Bowes et al., 2021).

COVID-19 is easily transmitted in congregate living situations, with early and devastating outbreaks being documented in nursing homes and jails (Kırbı1k et al., 2020; Lam-Hine et al., 2021). Beside these, other indoor settings such as schools (including universities), restaurants, and hospitals have been identified as having high risk for the spread of COVID-19 (Fox et al., 
medRxiv preprint doi: https://doi.org/10.1101/2021.12.29.21268516; this version posted January 1, 2022. The copyright holder for this preprint (which was not certified by peer review) is the author/funder, who has granted medRxiv a license to display the preprint in perpetuity.

It is made available under a CC-BY-NC-ND 4.0 International license .

2021; Lam-Hine et al., 2021). Many universities attempted to implement some type of

71 wastewater surveillance program during the early months of the pandemic, with varying degrees

72 of success (Gibas et al., 2021; Harris-Lovett et al., 2021; Karthikeyan et al., 2021). To effectively

73 detect and monitor outbreaks of COVID-19 in these indoor settings requires wastewater

74 surveillance capabilities at small spatial scales such as building level. The study reported in this

75 article is focused on building-level wastewater surveillance for COVID-19 monitoring from a

76 spatiotemporally explicit perspective.

77 Wastewater surveillance typically requires a set of sequential steps, including sample site setup, sample collection (including storage and shipping; per CDC Wastewater Surveillance strategy),

79 lab analysis, and subsequent analysis and visualization of wastewater testing results and associated data. Geographic Information Systems (GIS) methods have been applied for the management and mapping of spatially explicit data related to wastewater testing and COVID-19 monitoring, and dashboard techniques have gained increasing attention due to their visual presentation capabilities within web-based environments (Dong et al., 2020; Lan et al., 2021;

84 Naughton et al., 2021). Yet, most of the existing dashboards for COVID-19 and wastewater studies only concentrate on management and visualization of relevant spatial or spatiotemporal data; their support on spatial analytics and modeling capabilities is inadequate. Spatial analytics and modeling, however, are pivotal in discovering patterns of interest hidden in complicated spatiotemporal data, and providing predictive or scenario analysis capabilities for monitoring and mitigation of pandemic situations (Franch-Pardo et al., 2020). Spatial Decision Support Systems (SDSS) hold potential in filling this gap. 
medRxiv preprint doi: https://doi.org/10.1101/2021.12.29.21268516; this version posted January 1, 2022. The copyright holder for this preprint (which was not certified by peer review) is the author/funder, who has granted medRxiv a license to display the preprint in perpetuity.

It is made available under a CC-BY-NC-ND 4.0 International license .

SDSS, which originated from the domain of Geographic Information Science (Armstrong et al., 1986; Sugumaran \& Degroote, 2010), have been increasingly applied to assist with decision making within spatially explicit contexts. SDSS is based on (but more than) the integration of decision support systems and GIS, and provides inherent support for spatial analytics and modeling capabilities. This makes SDSS unique and powerful in informing decision making processes associated with complex spatial or spatiotemporal phenomena. A variety of applications such as environmental monitoring, natural resources, public health, transportation, and land use and land cover change have built SDSS to address complex decision problems within spatially explicit contexts (Delmelle et al., 2014; Keenan \& Jankowski, 2019; Sugumaran \& Degroote, 2010). In particular, driven heavily by Internet technologies and cyberinfrastructure (NSF, 2007), web-based SDSS has received much attention over the past few years (Lan et al., 2020; Lee et al., 2017; Tayyebi et al., 2016). While a growing body of the literature has highlighted the power of web-based SDSS, the applications of web-based SDSS for the resolution of complex spatiotemporal decision problems in general and small-scale wastewater surveillance for COVID-19 monitoring, in particular, remain scant.

In this article, we describe a web-based SDSS framework for building-level wastewater surveillance. We used a university campus (the main campus of the University of North Carolina at Charlotte) as a study case. This framework supports the automated synchronization and update of lab test results, space-time cluster analysis for identifying hotspots of COVID-19 incidents at the building level over time, and automated update of dashboards within web-based environments. The integration of these geospatial data and analytics capabilities play a critical role in providing timely information on COVID-19 incidents in the study region over time. 
medRxiv preprint doi: https://doi.org/10.1101/2021.12.29.21268516; this version posted January 1, 2022. The copyright holder for this preprint (which was not certified by peer review) is the author/funder, who has granted medRxiv a license to display the preprint in perpetuity.

It is made available under a CC-BY-NC-ND 4.0 International license .

113 Specifically, we focus on addressing the following sets of research questions in this study: 1) Are

114 there any space-time clusters of positive wastewater testing results at the building level and

115 where are they? 2) What are those sampling sites that exhibit similar responses over time in

116 terms of wastewater testing results and where are they?

117 The remainder of this article is organized using the following structure. In section 2, we discuss 118 the background and relevant literature of this study. In section 3, we present the study area and 119 data, the design of the entire web-based SDSS framework as well as its implementation. Section

1204 presents the results including space-time cluster analysis, and Section 5 gives relevant

121 discussion. Section 6 concludes this article.

\section{Literature Review}

\subsection{Wastewater Surveillance}

A typical workflow for building-level wastewater surveillance includes collection of a sample at

125 regular intervals with laboratory results within 24 hours of collection. Samples can be collected

126 using a variety of methods (Medema et al., 2020), ranging from collection of a sample volume at

127 one timepoint (a "grab" sample), to composites collected by passive sampling for example using

128 fibrous swabs (Liu et al., 2021), and composites collected using pump autosamplers which add to

129 the sample at regular intervals over the course of a day prior to collection. Once collected,

130 samples are processed and concentrated. A wide variety of methods are available for this

131 concentration step as well, and choice of method is governed by a combination of viral recovery

132 efficacy, cost, materials availability, and processing time, as described in our previous work

133 (Juel et al., 2021). RNA is extracted from the concentrated sample, and virus is quantified using 
medRxiv preprint doi: https://doi.org/10.1101/2021.12.29.21268516; this version posted January 1, 2022. The copyright holder for this preprint (which was not certified by peer review) is the author/funder, who has granted medRxiv a license to display the preprint in perpetuity.

It is made available under a CC-BY-NC-ND 4.0 International license .

134 a molecular detection protocol such as RT-qPCR or RT-ddPCR (Barua et al., 2021; Ciesielski et 135 al., 2021), which provides a viral concentration in terms of copies of virus per liter of wastewater collected. This value can be used effectively as a simple binary indicator of positivity, as

137 demonstrated in the pilot phase of our campus monitoring program (Gibas et al., 2021) but also

138 has the potential to connect the information about population size and volume of water used in 139 the building to provide an estimate of the number of individuals who might be SARS-CoV-2 140 positive (Sweetapple et al., 2022). Once a positive signal is detected, a decision is made about 141 whether to test all individuals in that building, after consulting institutional information about 142 individuals who have recently tested positive or been connected to that site via contact tracing. If 143 there are no previously-known individuals who are likely to be the source of the positive signal, 144 then the entire building population is subjected to clinical testing.

145 While many institutions and localities have deployed wastewater testing for SARS-CoV-2 during 146 the pandemic, only a small fraction of these projects have so far made data available in service of 147 larger efforts to develop quantitative models and consistent practices in wastewater 148 epidemiology (Naughton et al., 2021). Data dashboards are a common means for sharing such 149 information when it is made available, and in some cases have been incorporated into state-level 150 public health reporting (e.g., see https://covid19.ncdhhs.gov/dashboard/wastewater-monitoring).

151 Dashboard techniques have been extensively applied for the sharing of data related to COVID-

152 19. A number of dashboards have been developed and deployed to support the wastewater 153 surveillance initiatives for the monitoring of COVID-19 worldwide. For example, there are a 154 number of dashboards registered via the web site of COVIDPoops19 project (Naughton et al., 155 2021). About $40 \%$ of these dashboards have built-in Web GIS functionality. The software 
medRxiv preprint doi: https://doi.org/10.1101/2021.12.29.21268516; this version posted January 1, 2022. The copyright holder for this preprint (which was not certified by peer review) is the author/funder, who has granted medRxiv a license to display the preprint in perpetuity.

It is made available under a CC-BY-NC-ND 4.0 International license .

156

157

158

159

160

161

162

163

164

165

166

167

168

169

170

171

172

173

174

175

176

177

platforms used to present these dashboards include Esri ArcGIS Online, Tableau, R Shiny,

Microsoft Power BI, and CARTO. The first three (ArcGIS Online, Tableau, and R Shiny) are the dominant choices for the implementation of wastewater surveillance dashboards. Most of the wastewater data managed and reported by these wastewater dashboards are at the wastewater treatment plant level and collected weekly, while a smaller number of projects report daily or multiple days per week. A few universities make campus wastewater data available in real time via public dashboards (e.g. University of California at San Diego, Clemson University), but in other cases, for instance at the University of North Carolina at Charlotte, the concern of upper administration not to alarm students or parents with details of wastewater alerts has resulted in a decision to keep this information for internal use only. A number of existing dashboards only focus on the visual presentation (in maps or charts) of wastewater-related data, and may not provide the spatiotemporal analytics and modeling of wastewater testing results and relevant data. The need for spatiotemporal analysis and modeling to guide the study of wastewater testing results for the monitoring of COVID-19 outbreak and prevention has been recognized in the literature (Karthikeyan et al., 2021).

\subsection{Spatial Decision Support Systems}

SDSS are integrative computer-based systems that provide decision-making support for complex spatial problems via the fusion of spatial data management, modeling, and visualization capabilities (Densham, 1991; Malczewski, 1999; Sugumaran \& Degroote, 2010). SDSS, with an origin from Decision Support Systems (Marakas, 2003), are distinguished by their ability to handle decision-making support within a spatially explicit context via the incorporation of GISbased functionality. Yet, SDSS differ from GIS in that they encompass spatial modeling 
medRxiv preprint doi: https://doi.org/10.1101/2021.12.29.21268516; this version posted January 1, 2022. The copyright holder for this preprint (which was not certified by peer review) is the author/funder, who has granted medRxiv a license to display the preprint in perpetuity.

It is made available under a CC-BY-NC-ND 4.0 International license .

178

179

180

181

182

183

184

185

186

187

188

189

190

191

192

193

194

195

196

197

198

199

capabilities to aid decision-making (Armstrong et al., 1986; Sugumaran \& Degroote, 2010). For example, with the incorporation of a spatial simulation model, SDSS can enable what-if scenario analysis to explore potential alternative solutions of a spatial problem. The spatial optimization model helps SDSS identify spatially explicit optimal solutions facing decision makers (represented by site selection problems). Further, spatial statistical models allow for the discovery of spatial patterns of interest (e.g., clusters of disease or accidents) from spatial data. All these modeling capabilities can be built within a SDSS that informs and facilitates decision making processes associated with complex spatial or spatiotemporal problems (Ghosh, 2008). In terms of implementation, a SDSS includes the following functional modules: data management, model management, visualization and report generation, and a user interface (Armstrong et al., 1986; Densham, 1991; Sugumaran \& Degroote, 2010).

While the study of SDSS in early stages focuses on the development of conceptual architecture, cyberinfrastructure-enabled computing technologies such as web and cloud computing have been fostering the implementation and applications of SDSS into different domain studies (Sugumaran \& Degroote, 2010; Tang et al., 2017). For example, Mwaura and Kada (2017) presented a webbased SDSS in which a multi-criteria decision making model was used to evaluate potential sites of geothermal wells in Kenya, east Africa. Crimi et al. (2019) investigated the identification of priority regions in Bradford, UK for freight lorry parking within a web-based SDSS environment. Lan et al. (2020) applied web-based SDSS that guides the monitoring and sharing of water quality information of private wells in Gaston County, NC, USA. Spatial interpolation algorithms were used in Lan et al.'s work to generate the spatially continuous distribution of water quality that will inform residents or governments for potential water contamination. 
medRxiv preprint doi: https://doi.org/10.1101/2021.12.29.21268516; this version posted January 1, 2022. The copyright holder for this preprint (which was not certified by peer review) is the author/funder, who has granted medRxiv a license to display the preprint in perpetuity.

It is made available under a CC-BY-NC-ND 4.0 International license .

\section{Materials and Methods}

\subsection{Study Area and Data}

202

203

204

205

206

207

208

209

210

211

212

213

214

215

216

217

218

Our study area is the main campus of the University of North Carolina at Charlotte, USA (see

Fig. 1). The main campus of the University $\left(35^{\circ} 18^{\prime} 25^{\prime \prime} \mathrm{N}, 80^{\circ} 44^{\prime} 06^{\prime \prime} \mathrm{W}\right)$ is located in the north of the City of Charlotte (within Mecklenburg County). The University is an urban university with about 3,000 employees (including faculty and staff); and 30,146 students in the Fall semester of 2020. Among them, around 6,000 students are living in residential halls on campus. In total, there are 138 buildings in the main campus, 33 residence halls, 32 academic buildings, and 73 other types. Please see Appendix 1 for sources of the aforementioned information about the University. In terms of topography, the main campus is high in east and west and low in the middle (range of elevation: 176-226 meters). The slope of the main campus varies from $0^{\circ}$ to $25^{\circ}$ (based on a 1-m DEM derived from LiDAR point cloud data). The Toby Creek area is the lowest-lying region on campus. Toby Creek flows through the campus and discharges into Mallard Creek at the north end of the campus. The university's sewer system is composed of gravity sewer lines, where a sampling at a specific sewer manhole location will be affected by upstream nodes. Lateral and branch sewer lines collect wastewater from all residence and academic buildings, and then connect to a main sewer line (Charlotte Water's wastewater system) which parallels Toby Creek. Campus wastewater is treated at the nearby Mallard Creek Treatment Facility. 


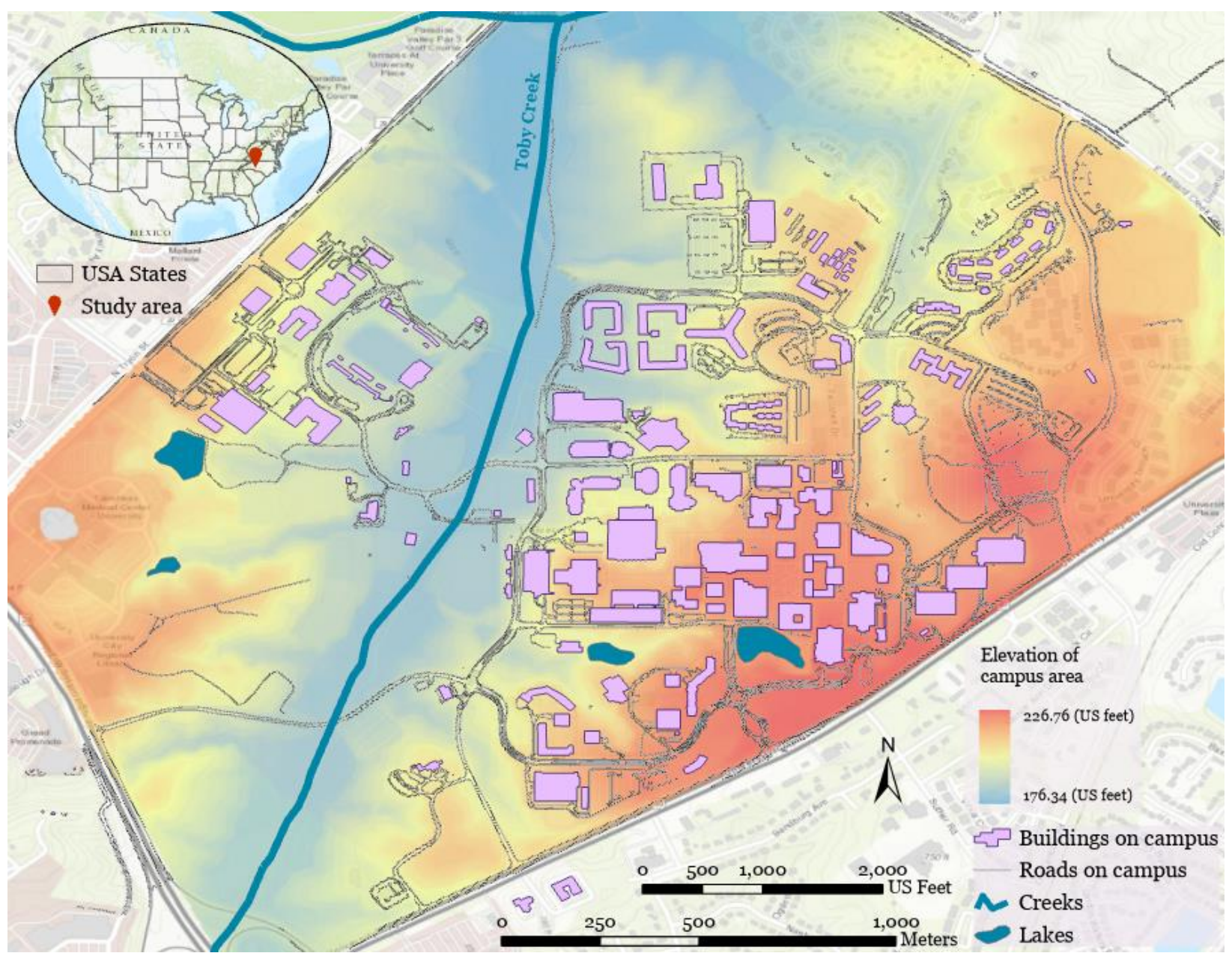

Fig. 1. Map of the main campus of the University of North Carolina at Charlotte, USA (sewage network details are not shown for the protection of physical security of university infrastructure). (WBE) surveillance program in late Summer 2020 to assist the University in monitoring COVID-19 incidence. Wastewater signal has been used since that time to identify dormitory populations for testing ("surge testing") in the event of detection of SARS-CoV-2 virus in the

227 absence of a previously identified source. The wastewater surveillance program has been collecting and analyzing wastewater samples since September, 2020. A team of faculty, staff, 
medRxiv preprint doi: https://doi.org/10.1101/2021.12.29.21268516; this version posted January 1, 2022. The copyright holder for this preprint (which was not certified by peer review) is the author/funder, who has granted medRxiv a license to display the preprint in perpetuity.

It is made available under a CC-BY-NC-ND 4.0 International license .

and students from bioinformatics, engineering, computer science, and geography collaborate to develop this monitoring system, with infrastructure support from the University's Facilities Management staff. The WBE team has also developed a Building Information Modeling (BIM; see Becerik-Gerber et al. (2012)) 3D model for each residence hall on campus. Each BIM model includes the building envelope and plumbing fixtures, which can be used to identify rooms and zones in which potential infected individuals are located. Wastewater data collected together with BIM models have allowed campus administration to make timely and targeted decisions to prevent the cluster outbreak and spread of COVID-19 on campus (see Gibas et al., 2021 for detail). We collected spatial data to support the wastewater surveillance work for our study area. These data include buildings, sewer lines, sampling sites, road network, and elevation.

Table 1. Spatial data collected for the wastewater surveillance work for the study area.

\begin{tabular}{lll}
\hline Spatial Data & Data source & GIS Data Format \\
\hline Buildings & Department of Facilities Management of UNC Charlotte & Polygon Vector \\
Sewer lines & Department of Facilities Management of UNC Charlotte & Polyline Vector \\
Sampling sites & Wastewater Surveillance Task Force Group at UNC Charlotte & Point Vector \\
Road network & Department of Facilities Management of UNC Charlotte & Polyline Vector \\
Elevation & U.S. Geological Survey, 3D Elevation Program & Raster \\
\hline
\end{tabular}

There are in total 38 sampling sites that were identified and established for wastewater collection since Fall 2020 (see Fig. 2 for illustration). These sampling sites are organized in two types: for residence halls (a sampling site covers a building or part of the building) and for buildings within a sub-sewershed - referred to as neighborhood site in this study (a sampling site covers multiple buildings). Manholes and plumbing cleanouts are selected to set up these sampling sites. As a manhole may connect to multiple sewage lines from different buildings, a manhole may have 
medRxiv preprint doi: https://doi.org/10.1101/2021.12.29.21268516; this version posted January 1, 2022. The copyright holder for this preprint (which was not certified by peer review) is the author/funder, who has granted medRxiv a license to display the preprint in perpetuity.

It is made available under a CC-BY-NC-ND 4.0 International license .

247 multiple auto-samplers with probes deployed in different directions (up to two in our study)

248 installed to collect sewage samples from different buildings. Further, a building (typically large)

249 may have two or more sampling sites each covering different parts of the building. These

250 sampling sites cover in total 89 buildings on campus for wastewater monitoring. We used a

251 Trimble GPS handheld unit (with a submeter accuracy) to obtain the coordinates of the sampling

252 sites. However, 10 of 38 samplers are located either very close to the building or inside the

253 building, which degrades the signal quality of GPS satellites. Therefore, their locations are

254 determined using Google Earth and images taken using a digital camera. One sampling site is

255 completely under trees with dense canopy, where we cannot determine its exact coordinates

256 using a GPS instrument or Google Earth imagery. In such a case, we used the location of the

257 corresponding manhole (identified from the GIS data of the sewage network) as the coordinates

258 of the sampling site.

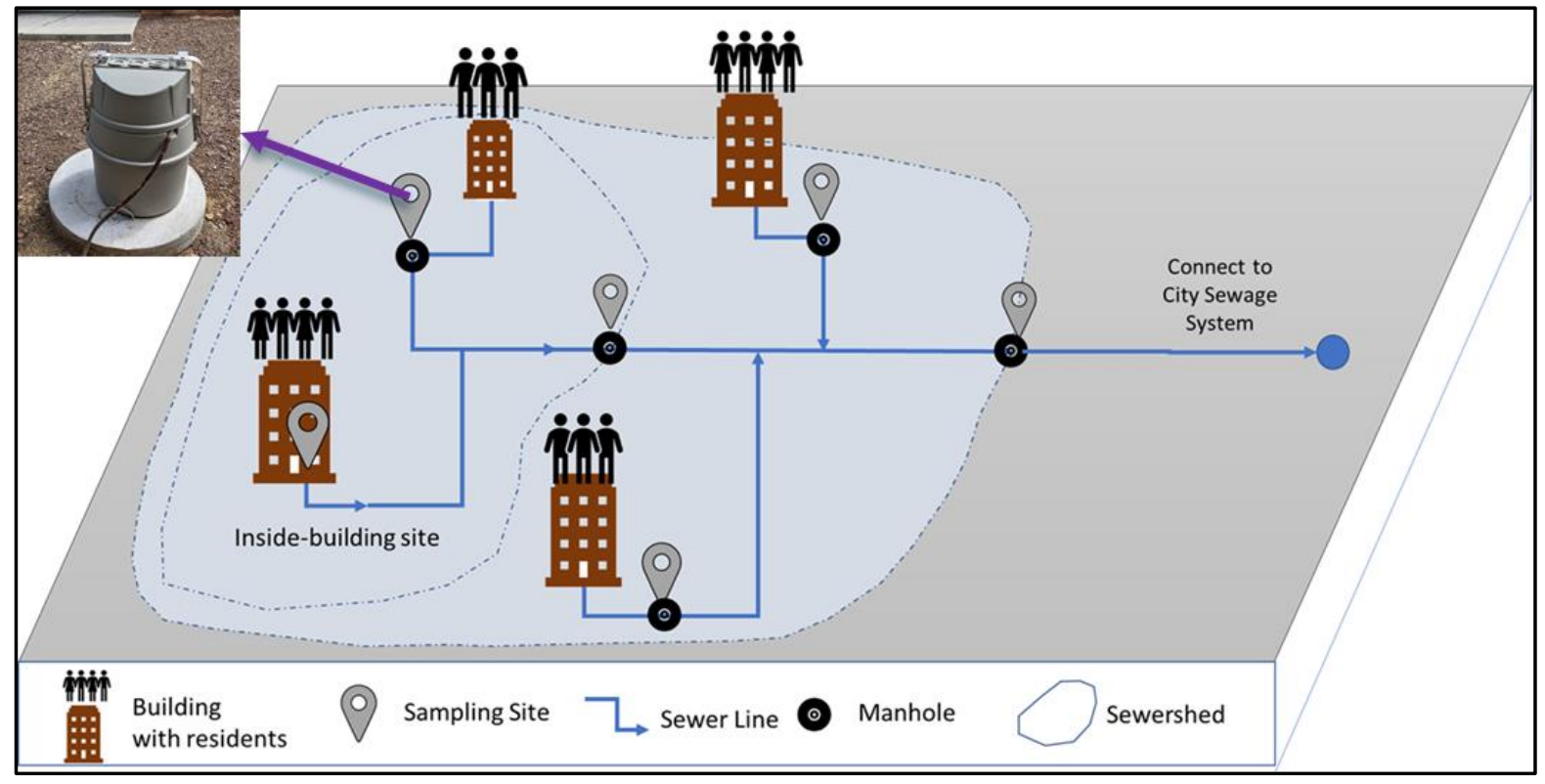

Fig. 2. Illustration of sampling site setup for building-level wastewater surveillance. 
medRxiv preprint doi: https://doi.org/10.1101/2021.12.29.21268516; this version posted January 1, 2022. The copyright holder for this preprint (which was not certified by peer review) is the author/funder, who has granted medRxiv a license to display the preprint in perpetuity.

It is made available under a CC-BY-NC-ND 4.0 International license .

\subsection{Methods}

263 In this section, we present the framework of the web-based SDSS and its main components. Fig.

2643 illustrates the design of the web-based SDSS framework for wastewater surveillance in this

265 study. This framework supports the data management, model management, and visualization of

266 wastewater data that are spatiotemporally explicit. The integration of these functionality allows

267 for the automated synchronization of wastewater testing results, on-demand spatiotemporal

268 analysis of COVID-19 incidents from wastewater results, and automatic update of Web GIS

269 dashboard that supports timely decision making in a spatially explicit manner.

270 Building-level wastewater surveillance typically includes three steps (see Gibas et al., 2021):

271 collection of wastewater samples, sample concentration and RNA extraction, and detection of

272 COVID-19 virus. Various sample-related data are generated from these steps. These data are

273 characterized with space-time stamps and associated with different sampling sites, buildings, and

274 sewersheds. Fundamentally, these data are space-time series that represent various information

275 related to wastewater testing over space and time. Mathematically, our wastewater surveillance

276 data (noted as $W$ ) can be formulated as in Eq. 1: 
medRxiv preprint doi: https://doi.org/10.1101/2021.12.29.21268516; this version posted January 1, 2022. The copyright holder for this preprint (which was not certified by peer review) is the author/funder, who has granted medRxiv a license to display the preprint in perpetuity.

It is made available under a CC-BY-NC-ND 4.0 International license .

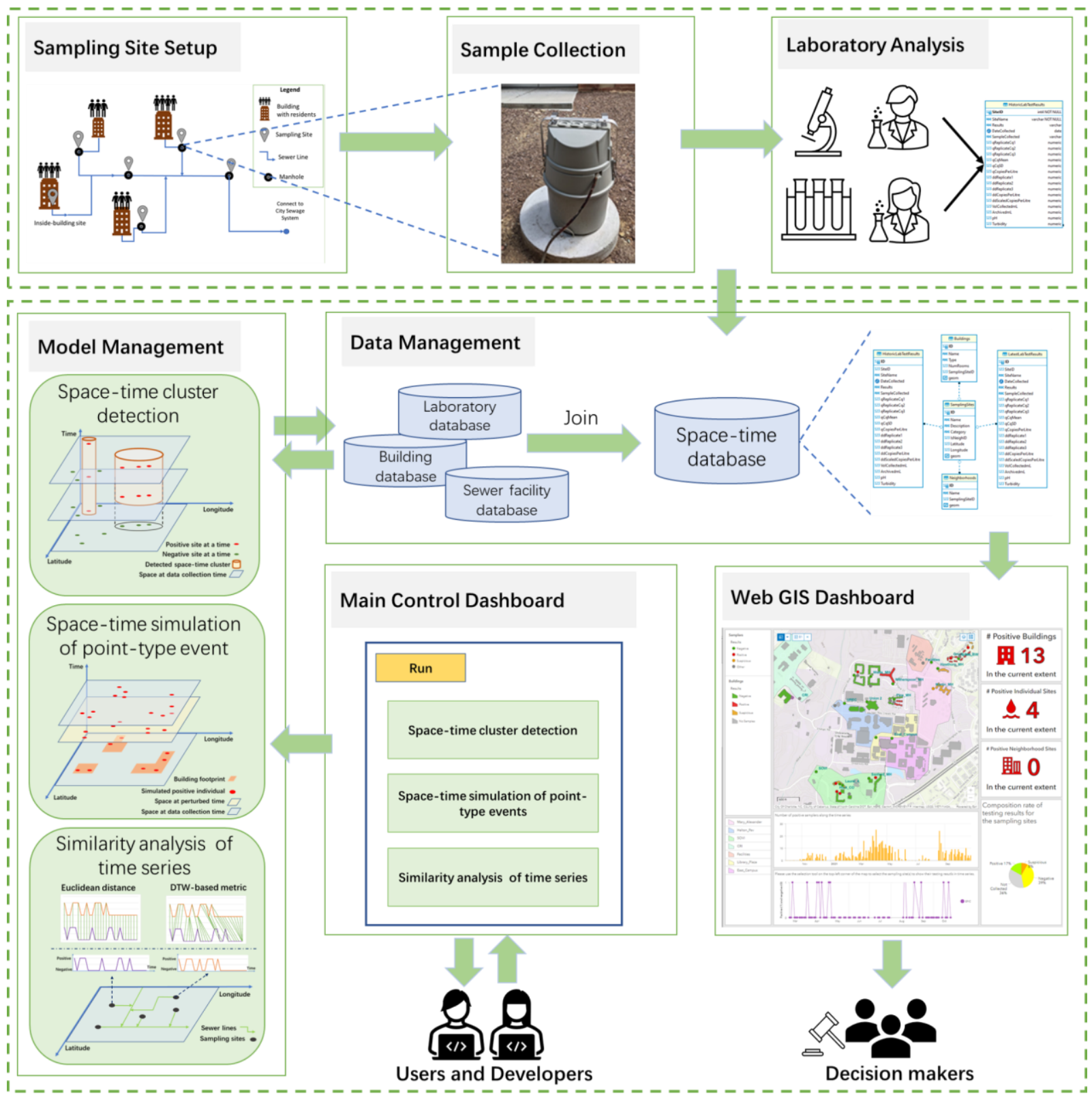

278 Fig. 3. Framework of the web-based spatial decision support system for wastewater surveillance.

281 where:

$i$ : sampling site ID, $i \in[1,2, \ldots, n] ; n$ : number of sampling sites;

$t$ : ID of time step; $t \in\left[t_{1}, t_{2}, \ldots, t_{m}\right]$; $t_{1}$ : beginning date of wastewater sampling; $t_{m}$ : end date of sampling; $m$ : number of sampling dates; 
medRxiv preprint doi: https://doi.org/10.1101/2021.12.29.21268516; this version posted January 1, 2022. The copyright holder for this preprint (which was not certified by peer review) is the author/funder, who has granted medRxiv a license to display the preprint in perpetuity.

It is made available under a CC-BY-NC-ND 4.0 International license .

\section{$i d$ : ID of the sample at site $i$ and time $t$.}

$w(i, t)$ : wastewater testing result for site $i$ at time $t(w(i, t)=\{0,1\}=\{$ negative, positive $\})$; $v_{1}(i, t), v_{2}(i, t), \ldots, v_{p}(i, t)$ : all other variables associated with site $i$ at time $t$; These variables may change over time or not (e.g., testing results will change over time but the ID of associated building(s) will not).

$p$ : number of other variables for a sampling site;

Among these variables, the wastewater testing result $w(i, t)$ is a binary variable that indicates

whether COVID-19 virus is detected (1: positive; 0: negative) for a sampling site on a specific

date. In this study, qPCR detection results from three sample replicates are used to determine

whether a sample is considered positive or not. When the virus concentration (mean $\mathrm{Cq}$ ) values

of all three sample replicates are lower (indicating higher viral load) than the empirically

determined limit of detection threshold, the corresponding wastewater sample is considered

positive. For the purposes of determining administrative response on campus, samples must have all three replicates producing signals to be considered "positive". Any samples that have only $2 / 3$ replicates producing signals are considered "suspicious" and 1 or fewer replicates producing signals considered negative. This "suspicious" designation is only used for administrative decision purposes. For more detail, please refer to Gibas et al. (2021). In our study here, samples that have 2 or less replicates producing signals are treated as negative (i.e., suspicious and negative samples are merged into a single category: negative).

\subsubsection{Spatiotemporal data management and data synchronization}

We developed an object-based spatiotemporal data model (see Fig. 4A) to represent spatiotemporally explicit information related to building-level wastewater surveillance for COVID-19 monitoring. Spatiotemporal data models have been developed to represent dynamic geospatial phenomena (Chen et al., 2016; Pelekis et al., 2004; Peuquet \& Duan, 1995). Based on 
medRxiv preprint doi: https://doi.org/10.1101/2021.12.29.21268516; this version posted January 1, 2022. The copyright holder for this preprint (which was not certified by peer review) is the author/funder, who has granted medRxiv a license to display the preprint in perpetuity.

It is made available under a CC-BY-NC-ND 4.0 International license .

spatiotemporal data models, data structures and databases can be designed and implemented to handle data with spatiotemporal stamps. A series of spatiotemporal data models have been proposed in the literature, including snapshot-based, event-based, and object-based (Pelekis et al., 2004). Our spatiotemporal data model is object-based, in which a spatiotemporal object represents a geospatial entity in space and time. As the geometry of sampling sites and buildings does not change, our spatiotemporal data model only needs to take into account change in attributes (non-spatial information) associated with sampling sites or buildings. Thus, a wastewater sample collected at a site at a specific date is abstracted as a spatiotemporal object associated with a set of variables, including sampling site information (geometry: point), building information (geometry: footprint polygon), and lab testing results. Fig. 4B is the entityrelationship (ER) diagram that we used to build the geodatabase based on the spatiotemporal data model. Database tables were created to manage the spatiotemporal data associated with wastewater surveillance (including sampling sites, buildings, sewersheds, historic lab testing results, and latest lab testing results). Further, we used a set of database tables to maintain the relationships between sampling sites and buildings, as well as sampling sites and sewersheds.

We developed an automated synchronization module to upload wastewater testing results once they are available (including real-time and historic data). This automated data synchronization module is implemented within a web-based interface. This synchronization module takes sample testing results (in a delimited file; CSV format) as input and associates these testing results with corresponding buildings or sewersheds (through SQL style left-joins). Then, these testing results are updated to the spatiotemporal database. 
medRxiv preprint doi: https://doi.org/10.1101/2021.12.29.21268516; this version posted January 1, 2022. The copyright holder for this preprint (which was not certified by peer review) is the author/funder, who has granted medRxiv a license to display the preprint in perpetuity.

It is made available under a CC-BY-NC-ND 4.0 International license .
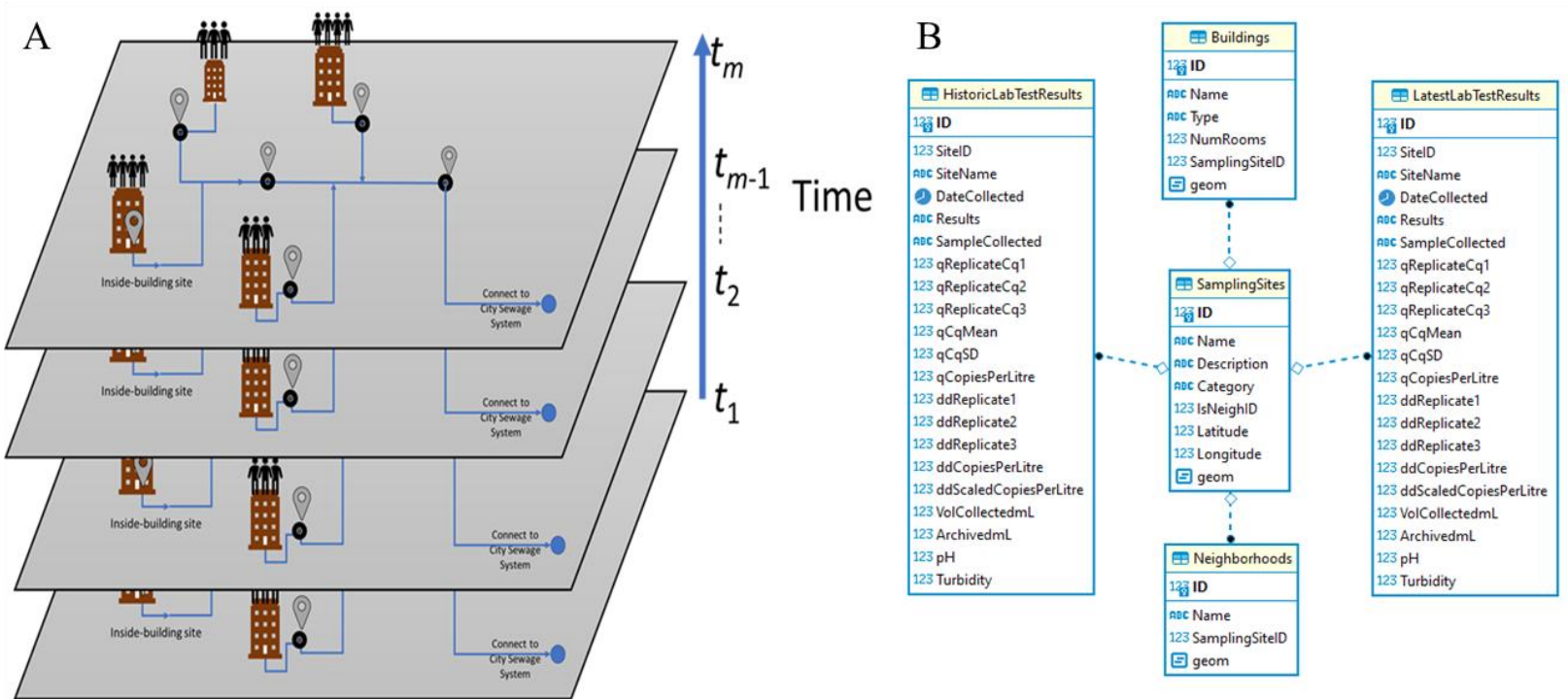

Fig. 4. Illustration of spatiotemporal data model (A) and entity-relationship diagram (B) for building-level wastewater surveillance.

\subsubsection{Spatiotemporal analysis of wastewater testing results}

To address the research questions aforementioned in the Introduction section requires the use of space-time analysis and modeling approaches. We chose to use space-time scan statistics, spacetime simulation of asymptomatic individuals, and similarity analysis of space-time series.

\subsubsection{Space-time scan for cluster detection}

In this study, we utilized space-time scan statistics for the detection of space-time clusters of positive wastewater samples reported from wastewater surveillance. We used Kulldorff's retrospective space-time scan statistic (Kulldorff, 1999; Kulldorff et al., 1998), implemented in SaTScan (version 9.6). A variety of studies have applied the space-time scan statistics approach to detect clusters of covid cases during the COVID-19 pandemic (see, e.g., Desjardins et al., 2020; Hohl et al., 2020; Kim \& Castro, 2020; Masrur et al., 2020). However, the space-time 
medRxiv preprint doi: https://doi.org/10.1101/2021.12.29.21268516; this version posted January 1, 2022. The copyright holder for this preprint (which was not certified by peer review) is the author/funder, who has granted medRxiv a license to display the preprint in perpetuity.

It is made available under a CC-BY-NC-ND 4.0 International license .

345 cluster detection for COVID-19 monitoring is often applied at large spatial or jurisdictional

346 scales (e.g., state or county level for a country). To our knowledge, this is the first time that the

347 space-time scan statistic is used to detect the presence of COVID19 in wastewater and at a small

348 spatial scale (building level).

349 The space-time scan statistics uses a cylinder-based scanning window to detect the cluster of

350 space-time objects (e.g., positive wastewater samples here; see Fig.5). The base of the cylinder

351 defines the geographic region covered by the scanning window (the radius of the base is the

352 spatial bandwidth) while the height represents the time duration of the scanning window (i.e.,

353 temporal bandwidth). When applying space-time scan statistics, the center of the cylinder is

354 placed at each spatial object (point-types; centroids can be used for polygon-type objects) and the

355 spatiotemporal bandwidth is varied. Then, by using a likelihood ratio test, the number of

356 observed events within and outside the cylinder is compared against their expected values based

357 on Poisson or Bernoulli models (Kulldorff, 1997). Events within a cylinder scanning window

358 with highest likelihood ratio (indication of elevated risk) are identified as a space-time cluster.

359 Monte Carlo approach can be used to test the significance of the cluster(s). As the wastewater

360 testing results are a binary variable (positive or negative) in this study, we used the Bernoulli

361 model for the probability model used by the space-time scan statistics. 


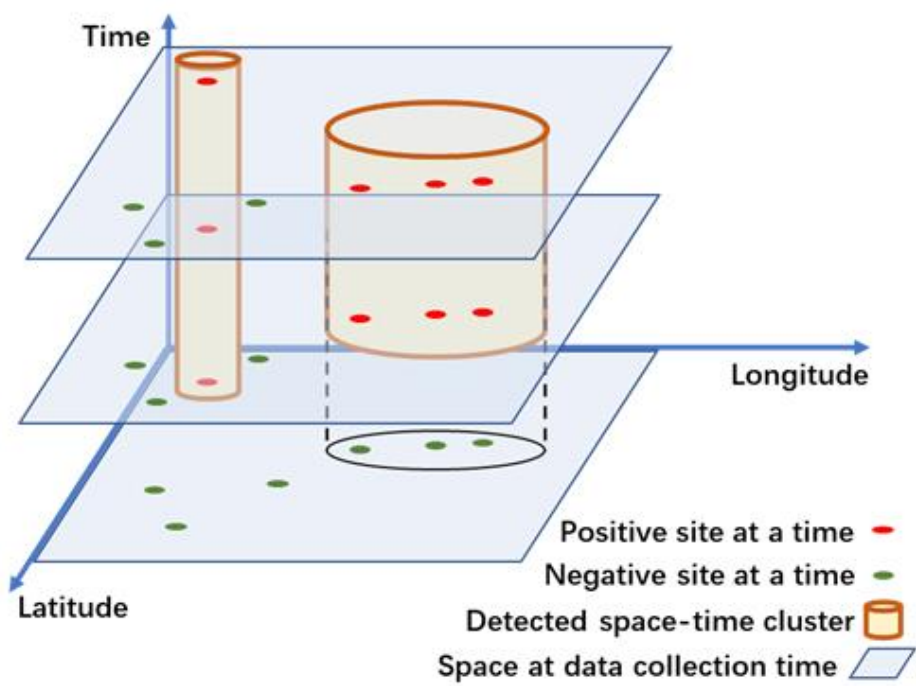

363 Fig. 5. Illustration of using cylindrical scanning windows for space-time scan statistics.

\subsubsection{Space-time simulation of asymptomatic individuals}

In this study, wastewater testing results from a sampling site are indicative of the situation of the associated building(s)--whether there are presymptomatic individuals in the building. However, the location of the individual(s) within the building is unknown (for privacy protection)—i.e., spatial uncertainty. Further, collected samples on a particular day may be reflective of a prior contamination, keeping in mind that samples were collected every two days or more instead of every day in our study-i.e., temporal uncertainty. Therefore, we used a space-time point pattern

372 simulation approach (see Diggle, 2013) to generate the locations of presymptomatic individuals

373 within the associated building (footprint in polygonal form) and the time that the individuals

374 begin to shed virus. In other words, this approach allows us to simulate space-time locations

375 (where and when) of the presymptomatic individuals, represented as space-time objects in this study. 
medRxiv preprint doi: https://doi.org/10.1101/2021.12.29.21268516; this version posted January 1, 2022. The copyright holder for this preprint (which was not certified by peer review) is the author/funder, who has granted medRxiv a license to display the preprint in perpetuity.

It is made available under a CC-BY-NC-ND 4.0 International license .

377 Fig. 6 illustrates the algorithm of the simulation of space-time point patterns of asymptomatic

378 individuals within buildings. The space-time point pattern simulation begins with footprint

379 polygons of all sampled buildings to determine the spatial location of an asymptomatic

380 individual. A point is randomly generated within the bounding box of the footprint of each

381 building. The point is retained if it is located within the building footprint polygon. Once the

382 spatial location of the presymptomatic individual is determined, the date that the individual

383 begins to shed virus is obtained by randomly perturbing the original sampling date up to

$384 \quad n \_p e r t u r b$ days before (e.g., $n \_p e r t u r b=3$ in this study). This procedure is applied to each

385 building for a number of Monte Carlo repetitions (e.g., 1,000 repetitions used in this study).

386 After the space-time location is determined, associated sampler site data and testing results are

387 joined. The number of days for perturbation is based on the sampling frequency within a week.

388 For example, 3 days could be used to cover the tri-weekly testing interval. Once simulated

389 results are generated, space-time cluster analysis can be performed on these simulated

390 spatiotemporal point patterns to examine the robustness of space-time clusters detected from

391 observed data.

392

Algorithm for simulation of spatiotemporal point patterns of asymptomatic individuals

Parameters:

n_monte: number of Monte Carlo runs

$n \_$perturb: number of days for temporal perturbation

Begin Algorithm

For each Monte Carlo run of $n \_$monte repetitions

For each sampling record (associated with a building and time)

Randomly generate a point within the building footprint for the sample site;

Randomly generate the time by perturbing sampling date up to $n \_$perturb days before;

End for sampling record

End for Monte Carlo run

End Algorithm

Fig. 6. Algorithm of simulation of space-time locations of asymptomatic individuals. 


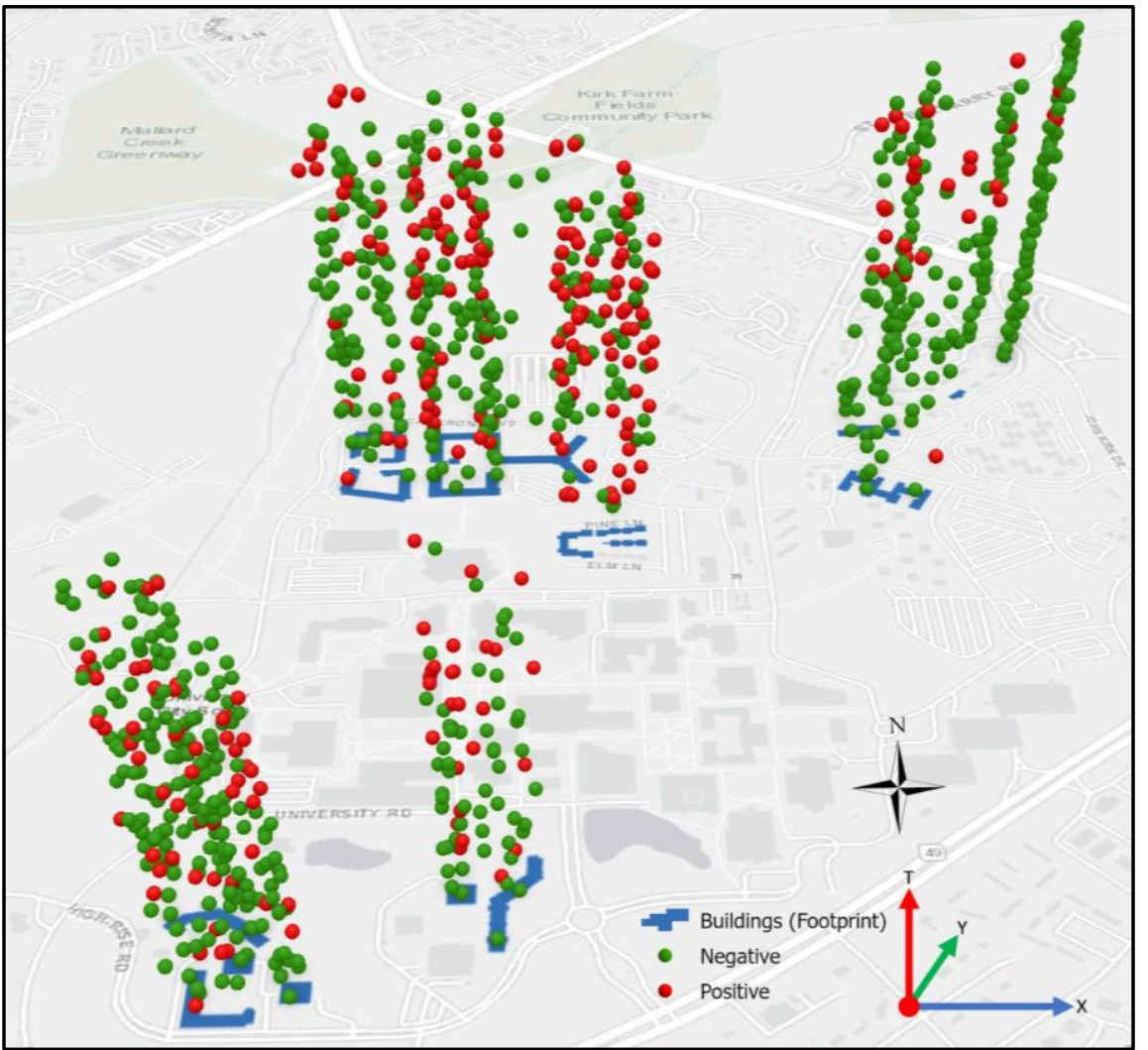

Fig. 7. Illustration of a simulated space-time point pattern of asymptomatic individuals (simulated period: January $4^{\text {th }}, 2021$ to May $18^{\text {th }}, 2021$; number of samples: 926 ; number of positive samples: 264; number of days for perturbation: 3 ).

\subsubsection{Similarity analysis of space-time series}

To investigate whether any sampling sites show similar responses over time in terms of wastewater testing results, we introduced similarity analysis of time series. We used two similarity metrics, Euclidean distance-based and Dynamic Time Warping (DTW)-based, in this study. Euclidean distance-based metric is a dissimilarity index that evaluates the distance of two time series in the temporal dimension (see Choi et al., 2010). The DTW-based metric allows for comparing time series in terms of shape (see Berndt \& Clifford, 1994). DTW is a method that computes the optimal matching between time series (or any sequence patterns) by minimization 
medRxiv preprint doi: https://doi.org/10.1101/2021.12.29.21268516; this version posted January 1, 2022. The copyright holder for this preprint (which was not certified by peer review) is the author/funder, who has granted medRxiv a license to display the preprint in perpetuity.

It is made available under a CC-BY-NC-ND 4.0 International license .

408

409

410

411

412

413

414

415

416

417

418

419

420

421

422

423

424

425

426

427

428

429

430

431

of distances (Aghabozorgi et al., 2015; Berndt \& Clifford, 1994). Given sampling site $i$ and $j$, Euclidean distance-based metric (noted as $D_{i j}$ ) between time series of their wastewater testing results can be calculated by Eq. (2). The DTW-based measure (noted as $D T W_{i j}$ ) is represented using the shortest cumulative distance between the beginning and end time steps of wastewater testing results at site $i$ and $j$ once matching between the two time series is optimized (see Eq. 3).

$$
\begin{array}{ll} 
& D_{i j}=\left(\sum_{k=1}^{m}\left(w\left(i, t_{k}\right)-w\left(j, t_{k}\right)\right)^{2}\right)^{1 / 2} \\
& D T W_{i j}=C_{i j}(m, m)=d_{i j}(m, m)+\min \left(C_{i j}(m-1, m-1), C_{i j}(m-1, m), C_{i j}(m, m-1)\right) \\
\text { s.t. } & \\
& C_{i j}(0,0)=0 \\
& d_{i j}(k, l)=\left|w\left(i, t_{k}\right)-w\left(j, t_{l}\right)\right|
\end{array}
$$

where $\mathrm{D}_{i j}$ and $D T W_{i j}$ are the Euclidean distance metric and the dynamic time warping metric of the time series between site $i$ and $j . \mathrm{w}\left(i, t_{k}\right)$ is the binary testing result of sampling site $i$ at time $t k$, and $\mathrm{w}\left(j, t_{l}\right)$ the binary testing result site $j$ at time $t_{l}(k, l \in\{1,2, \ldots, m\} ; m$ : number of sampling dates; defined in Eq. 1). $C_{i j}(k, l)$ is the alignment cost between time step $t_{k}$ of site $i$ and time step $t_{l}$ of site $j . d_{i j}(k, l)$ is the distance between time step $t_{k}$ of site $i$ and time step $t_{l}$ of site $j .|$.$| is the$ absolute function that calculates the absolute distance between site $i$ and $j . \min ($.$) is the function$ to calculate the minimum of costs. The DTW-based measure is derived using a dynamic programming approach (see Sakoe \& Chiba, 1978). Each similarity measure is based on the comparison of two time series, which leads to a $n$ by $n$ matrix of similarity for our wastewater case (n: number of sampling sites; see Eq. 1). Once similarity measures are calculated, hierarchical clustering can be applied to these similarity metrics to compare time series of wastewater testing results of all sampling sites. 
medRxiv preprint doi: https://doi.org/10.1101/2021.12.29.21268516; this version posted January 1, 2022. The copyright holder for this preprint (which was not certified by peer review) is the author/funder, who has granted medRxiv a license to display the preprint in perpetuity.

It is made available under a CC-BY-NC-ND 4.0 International license .

\subsubsection{Web-based mapping and geovisualization}

433 We used a Web GIS approach (Fu \& Sun, 2011; see Peng \& Tsou, 2003) for the visual

434 presentation of wastewater data and related spatiotemporal analysis results. Based on the

435 spatiotemporal data model, wastewater data are organized in a spatiotemporal database. We

436 publish these spatially explicit data (sampling sites, sewage network, buildings) into geospatial

437 web services that can be mashed up on a client-side web-based dashboard. When new

438 wastewater testing results are available or the previous sample results are updated, the Web GIS

439 module will automatically update these spatiotemporal data (via API) to the client-side web

440 dashboard (including data, charts, and maps). Further, when new sampling sites are added or

441 some existing sites are retired, the Web GIS module allows for updating spatial data and their

442 geospatial web services (e.g., sampling sites in points, sewersheds in polygons).

443 We used Esri ArcGIS Online (https://www.arcgis.com/) for Web GIS-based dashboard and

444 ArcGIS API for the automated update of wastewater data to the dashboard. Fig. 8 shows the

445 snapshot of our Web GIS dashboard. The web mapping interface shows the locations of

446 buildings, samplers, and sewersheds (aka, neighborhoods), and sewer networks (hidden for

447 confidentiality consideration). Moreover, the color scheme of samplers and buildings indicate the

448 sample testing results (shown in the map legend). Summary of wastewater testing results

449 including number of positive buildings, sampling sites, sewershed sites, and their time series is

450 displayed (for example, in charts). This provides visual and interactive analytics support that can

451 inform decision makers for subsequent decision making on, for example, clinical testing or

452 contract tracing. 
medRxiv preprint doi: https://doi.org/10.1101/2021.12.29.21268516; this version posted January 1, 2022. The copyright holder for this preprint (which was not certified by peer review) is the author/funder, who has granted medRxiv a license to display the preprint in perpetuity.

It is made available under a CC-BY-NC-ND 4.0 International license .

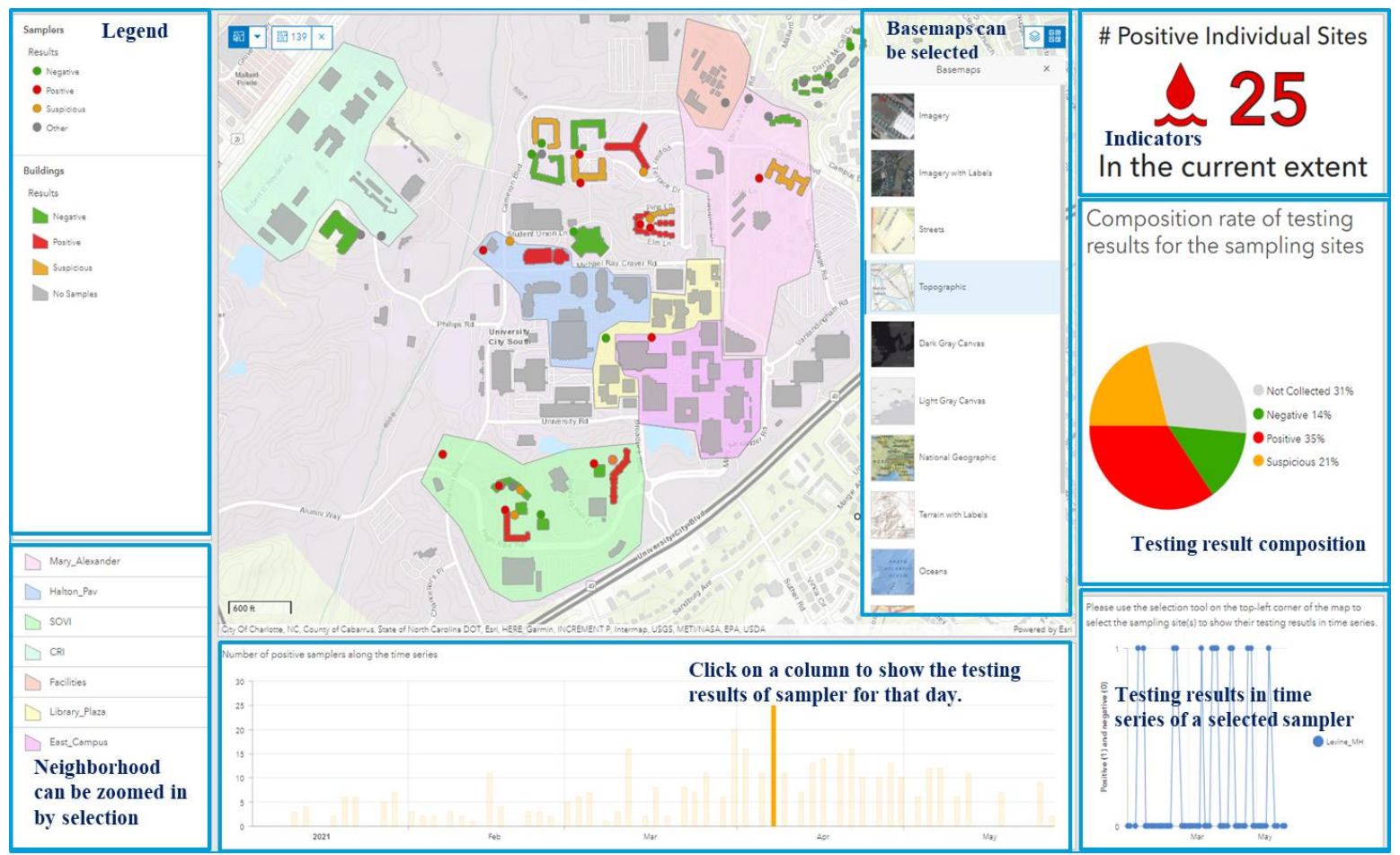

Fig. 8. Snapshot of the Web GIS dashboard (sewer networks is hidden due to confidentiality consideration).

\subsubsection{Implementation}

Our web-based SDSS is implemented within a web server. Jupyter Notebooks

(https://jupyter.org/) were used to implement the web-based main interface of the SDSS and access to its individual modules. Table 2 shows the software or libraries used to implement each individual module of the SDSS. We use ArcGIS API for Python to update wastewater testing results to the Web GIS dashboard based on ArcGIS Online. Google OAuth was chosen as the authentication mechanism of a web-based system for automated data synchronization. 
medRxiv preprint doi: https://doi.org/10.1101/2021.12.29.21268516; this version posted January 1, 2022. The copyright holder for this preprint (which was not certified by peer review) is the author/funder, who has granted medRxiv a license to display the preprint in perpetuity.

It is made available under a CC-BY-NC-ND 4.0 International license .

467 Table 2. Software or libraries used by the web-based SDSS for wastewater surveillance.

\begin{tabular}{llll}
\hline Module name & Sub-module & Software/Library & URL \\
\hline $\begin{array}{l}\text { Module for } \\
\text { geospatial database } \\
\text { design and data } \\
\text { synchronization }\end{array}$ & $\begin{array}{l}\text { Web interface for data } \\
\text { synchronization }\end{array}$ & $\begin{array}{l}\text { ArcGIS API for Python } \\
\text { (v1.9.1) }\end{array}$ & $\begin{array}{l}\text { https://developers.a } \\
\text { Fcgis.com/python/ } \\
\text { https://flask.pallets } \\
\text { projects.com }\end{array}$ \\
\hline & $\begin{array}{l}\text { Space-time cluster } \\
\text { detection }\end{array}$ & SatScan & $\begin{array}{l}\text { https://www.satsca } \\
\text { n.org/ }\end{array}$ \\
$\begin{array}{l}\text { Module for } \\
\text { Spatiotemporal } \\
\text { analysis }\end{array}$ & $\begin{array}{l}\text { of point-type events } \\
\text { Similarity measures of } \\
\text { time series }\end{array}$ & $\begin{array}{l}\text { TSdist v3.1 - Distance } \\
\text { Measures for Time }\end{array}$ & $\begin{array}{l}\text { https://cran.r- } \\
\text { project.org/web/pa } \\
\text { ckages/TSdist/inde } \\
\text { x.html }\end{array}$ \\
& Series in R & $\begin{array}{l}\text { https://www.arcgis. } \\
\text { com/index.html }\end{array}$ \\
\hline $\begin{array}{l}\text { Module for web- } \\
\text { based mapping and } \\
\text { geovisualization }\end{array}$ & Web GIS dashboard & Esri ArcGIS Online & \\
\hline
\end{tabular}

\section{Results}

\subsection{Overall results}

471 Our wastewater surveillance initiative has been collecting wastewater data since Fall 2020. We

472 have established 38 sampling sites since then. These sites provide strong support for monitoring

473 the COVID-19 situation via the wastewater surveillance approach. Wastewater testing results are

474 uploaded, synchronized, processed, analyzed, and visualized via the web-based SDSS. In this

475 study, we focus on using wastewater testing results from 23 residence hall sites from

476 01/04/2021 to 05/18/2021 (in total 135 days) as we have consistently used these sites to collect

477 samples during this period (results for neighborhoods sites and sampling sites of residence halls

478 that were established or removed during this period were excluded). Sewage samples were

479 collected three times a week on Monday, Wednesday, and Fridays for Spring 2021. This leads to 
medRxiv preprint doi: https://doi.org/10.1101/2021.12.29.21268516; this version posted January 1, 2022. The copyright holder for this preprint (which was not certified by peer review) is the author/funder, who has granted medRxiv a license to display the preprint in perpetuity.

It is made available under a CC-BY-NC-ND 4.0 International license .

480

481

482

483

484

485

486

487

488

489

490

491

492

493

494

495

496

497

498

499

500

501

54 sample collections for each sampling site during the study period (18 weeks times 3

collections per week). However, it is not always possible to collect a sample at every site every

time due to variations in flow or unexpected physical obstruction of the autosampler probe. As a result, 926 samples were collected from these 23 sites for Spring 2021. Among them, there are 662 negative $(71.49 \%)$, and 264 positive $(28.50 \%)$.

Fig. 9 depicts the number of positive sampling sites during the study period compared to the 7day averaged number of cases in Mecklenburg County, $\mathrm{NC}$ (original data is retrieved from the U.S. Centers for Disease Control and Prevention, https://ephtracking.cdc.gov/DataExplorer/). As we could see, the number of positive sites fluctuates between 0 and 8 before March $24^{\text {th }}, 2021$. After that date, an increasing pattern in terms of the number of positive sampling sites can be observed and lasts for about 2 weeks. This number reaches its maximum (16) on April $9^{\text {th }}, 2021$. After April $9^{\text {th }}$, the number drops to under 10 and tends to show a decreasing pattern over time.

The spring semester of the University was postponed to start from January $20^{\text {th }}, 2021$ and Spring Break was changed to the week from February $8^{\text {th }}$ to $13^{\text {th }}$, which was a decision made by the university due to the consideration of the pandemics (number of cases in Mecklenburg County is high in January and February; see Fig. 9). This explains the lower number of positive wastewater samples during the early stage of the semester. An increase in the number of cases in Mecklenburg County (corresponding to the local peak of the SARS-CoV-2 Alpha variant) appeared from mid March to mid April, 2021. Relaxation of local COVID-19 restrictions may also have contributed to this peak (see Executive Orders No. 195 and No. 204 by the North Carolina Governor on February $26^{\text {th }}$ (NC government, 2021a) and March $26^{\text {th }}$ (NC government, 2021b)). This corresponds to (and may explain) a dramatic increase in the number of positive 
medRxiv preprint doi: https://doi.org/10.1101/2021.12.29.21268516; this version posted January 1, 2022. The copyright holder for this preprint (which was not certified by peer review) is the author/funder, who has granted medRxiv a license to display the preprint in perpetuity.

It is made available under a CC-BY-NC-ND 4.0 International license .

502

503

504

505

506

507

508

509

510

511

512

513

514

515

516

517

samples on campus during that period. Decreasing trends appeared from mid to late April, 2021 in Mecklenburg County in terms of number of cases and on campus with respect to the number of positive wastewater samples. This can be attributed to the availability of vaccines to more people (increase in vaccination rate). Students started to receive vaccines beginning on March $31^{\text {st }}, 2021$, and vaccines were available to all adults in North Carolina by April $7^{\text {th }}$ (Source:

https://governor.nc.gov). Two on-campus vaccine clinics (March 31 ${ }^{\text {st }}, 2021$, and April $12^{\text {th }}$, 2021) hosted by the university facilitated vaccine uptake by students and faculty. All of these vaccine-related events play an important role in contributing to the decreasing number of positive samples in the final weeks of the semester.

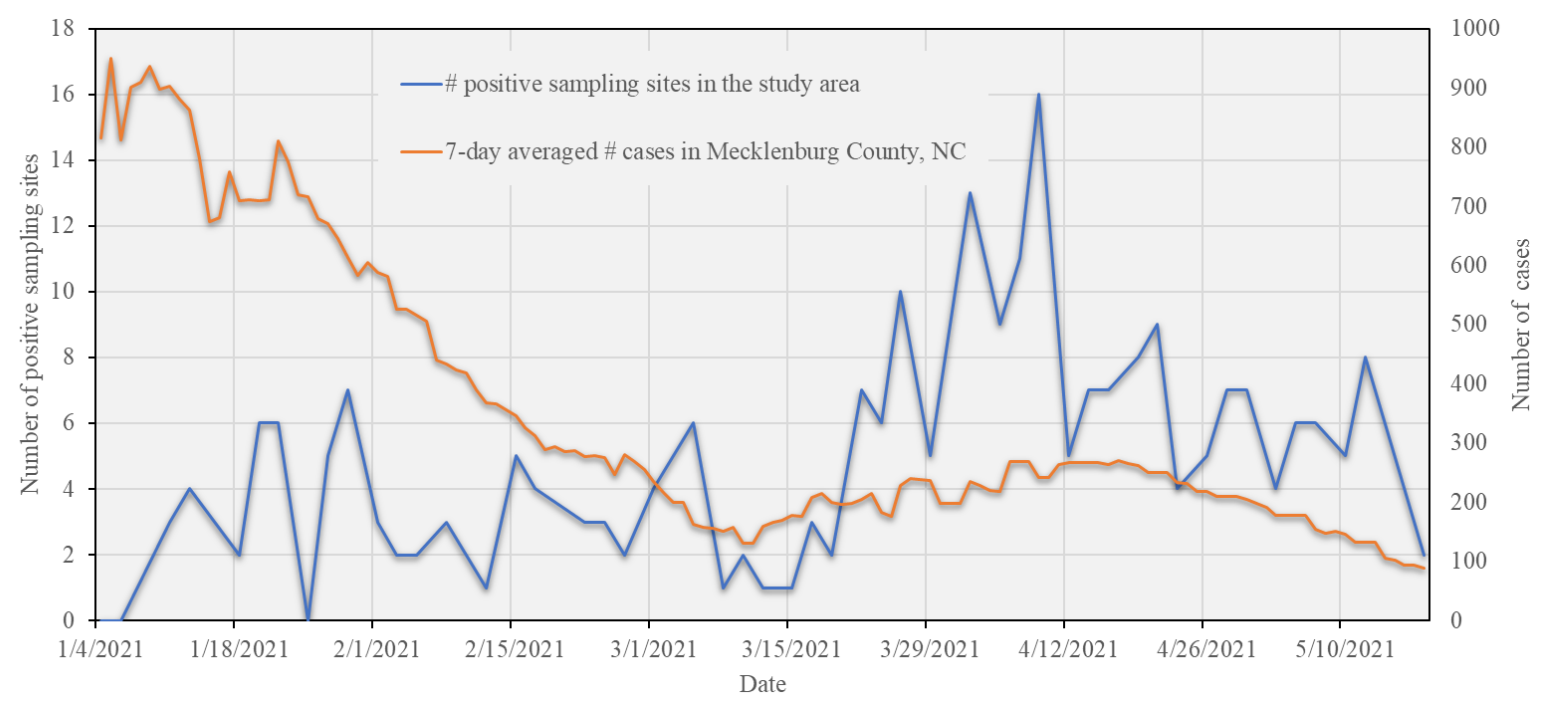

Fig. 9. Number of positive sampling sites in the study area and 7-day averaged number of cases in Mecklenburg County, NC over the study period.

\subsection{Results of space-time cluster analysis}

The use of space-time scan statistics needs to determine the upper limit of the spatiotemporal cluster size bandwidth (spatial bandwidth and temporal bandwidth). For the upper limit of the spatial bandwidth, we set the maximum spatial cluster parameter (corresponding to the 
medRxiv preprint doi: https://doi.org/10.1101/2021.12.29.21268516; this version posted January 1, 2022. The copyright holder for this preprint (which was not certified by peer review) is the author/funder, who has granted medRxiv a license to display the preprint in perpetuity.

It is made available under a CC-BY-NC-ND 4.0 International license .

percentage of population at risk-i.e., number of collected samples for this study) as $50 \%$. The upper limit of the temporal bandwidth is set to $50 \%$ of the duration of the study period.

\subsubsection{Space-time cluster analysis results based on samples collected from sampling sites}

Fig. 10 and Table 3 depict the space-time scan results based on the collected samples for which

the locations of samplers were used as coordinates for space-time scan analysis. Fig. 10 shows

the map of detected space-time clusters. One significant cluster (p-value under 5\%; based on 999

Monte Carlo runs) was detected that contains two sampling sites lasting from March $17^{\text {th }}, 2021$

to April $30^{\text {th }}, 2021$ (in total 44 days--about 7 weeks). These two sampling sites cover three residence halls. Both the total number of collected samples (population for space-time scan) and number of positive samples (cases) are 34, indicating all collected samples are positive in the detected space-time cluster during these 7 weeks. The detection of this significant cluster is because the three buildings have been used by the University for isolation and quarantine purposes. The relative risk is 3.88 in the detected cluster, indicating the residence halls covered by the sampling sites within the clusters are around 3-4 times higher than those out of the clusters in terms of the ratio of number of positive samples over expected value.

Table 3. Information of the detected space-time cluster based on locations of sampling sites.

\begin{tabular}{l|c|l}
\hline Parameter & \multicolumn{1}{|c|}{ Value } & Description \\
\hline Time span & $3 / 17 / 2021$ to $4 / 30 / 2021$ & Start date and end date of the cluster \\
\hline Population & 34 & Number of collected samples \\
\hline Number of cases & 34 & \begin{tabular}{l} 
Number of positive samples \\
\hline Expected cases
\end{tabular} \\
\hline Estimated risk & 3.69 & $\begin{array}{l}\text { The number of samples within the cluster multiplied } \\
\text { by the ratio of the total number of positive samples } \\
\text { over the total number of samples for the entire study } \\
\text { region. }\end{array}$ \\
\hline Relative risk & 3.88 & $\begin{array}{l}\text { The ratio of the number of positive samples within } \\
\text { the cluster over the number of expected cases within } \\
\text { the cluster }\end{array}$ \\
\hline p-value & $5.2 \mathrm{E}-15(\mathrm{p}<=0.05)$ & $\begin{array}{l}\text { The ratio of the estimated risk within the cluster over } \\
\text { that outside of the cluster }\end{array}$ \\
\hline
\end{tabular}




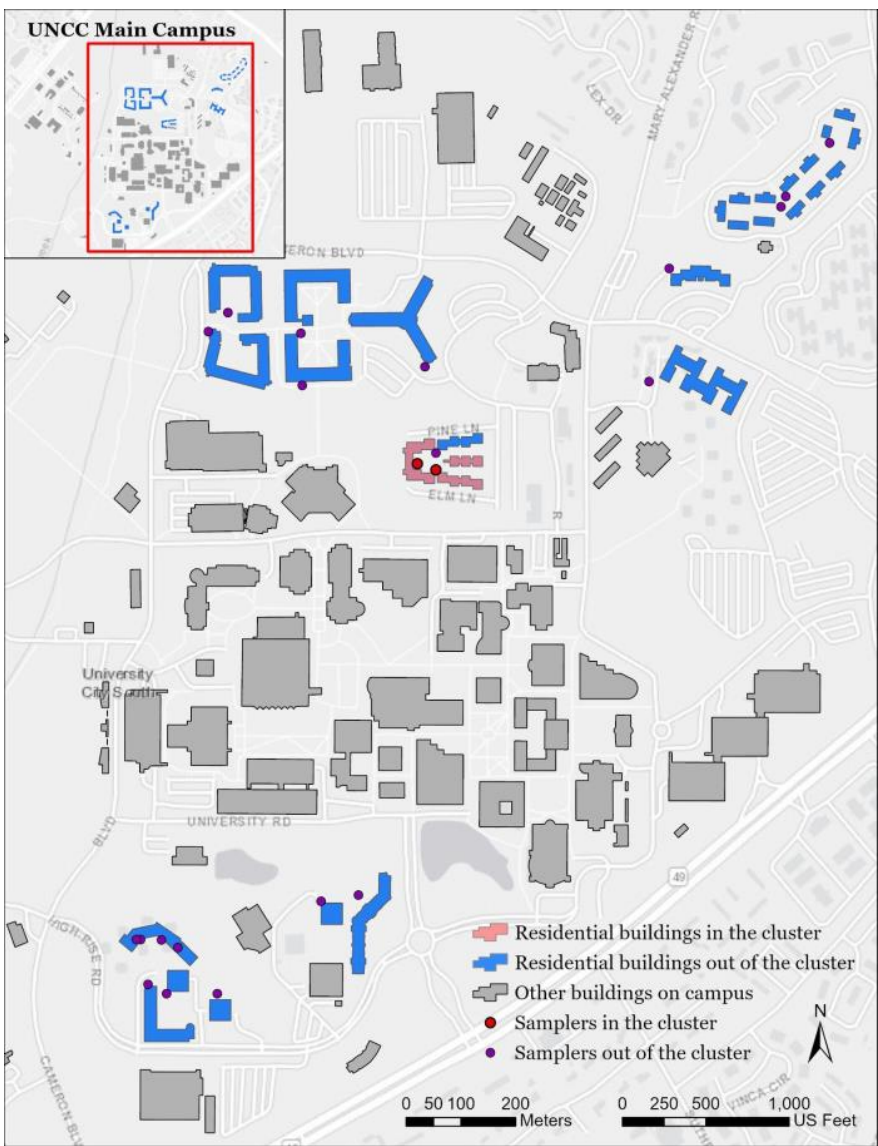

Fig. 10. Map of the sampling sites in the detected cluster and corresponding residence halls (sewer networks were hidden due to confidentiality consideration)

\subsubsection{Space-time cluster analysis results from simulated space-time point patterns}

The space-time scan results using locations of collected samples are based on sampling sites. In our case study, these wastewater samples were contributed from individuals living in their residence halls. Our sampling sites are, however, either outside or inside of residence halls, thus posing an issue of locational uncertainty. To address this issue, we used the space-time simulation of point-type events. We associate the binary (positive/negative) wastewater sampling results from sampling sites back to the residence halls. For those sites that cover a single building, once the wastewater testing result from any of these sites is positive, the residence hall will exhibit a positive signal. For a sampling site that covers multiple buildings, all these covered 
medRxiv preprint doi: https://doi.org/10.1101/2021.12.29.21268516; this version posted January 1, 2022. The copyright holder for this preprint (which was not certified by peer review) is the author/funder, who has granted medRxiv a license to display the preprint in perpetuity.

It is made available under a CC-BY-NC-ND 4.0 International license .

547 buildings will be positive if the testing results from the site are positive. The number of

548 simulations for generating space-time point patterns was set to 1,000 in this study.

549 Fig. 11 shows the spatial pattern of residence halls within the detected clusters from 1,000

550 simulated space-time point patterns (if a simulated presymptomatic individual within a building

551 belongs to a cluster, then we consider the building is within the cluster). There are 8 residence

552 halls that are within significant space-time clusters (at a 95\% confidence level). We hide the

553 names of the residence halls for confidentiality purposes. Table 4 summarizes the information of

554 detected clusters based on the 1,000 simulated space-time point patterns. Relative risk within

555 clusters is 2.774 , indicating the estimated risk of residence halls within the cluster is 2-3 times

556 higher than that outside the cluster.

557 Table 5 depicts start and end dates of each building within clusters, and Table 6 illustrates the

558 number of weeks that the detected space-time clusters from 1,000 simulations last. Fig. 12 shows

559 the histogram of the number of clusters in terms of the start date and end date of a building

560 within detected clusters. It can be observed from Table 6 that detected clusters last from 1 week

561 to 6 weeks, and $92.8 \%$ of the clusters last around 3-5 weeks. In general, the significant start date

562 of clusters on each building at high risk concentrates on March $24^{\text {th }}, 2021$ (one exception is

563 March $26^{\text {th }}$ for building 7) and most of them end around April $23^{\text {rd }}$ or $24^{\text {th }}$ (April $20^{\text {th }}$ for building

564 7), lasting around 1 month. This suggests that the wastewater signals from these 8 buildings

565 correspond to the second peak of the pandemic in Mecklenburg County (see Fig. 9). The three

566 buildings used for isolation and quarantine purposes are included in these 8 buildings. 
Table 4. Summary of the clusters detected in 1,000 simulated datasets.

\begin{tabular}{l|c|c|c|c|c}
\hline & Mean & $\begin{array}{c}\text { Standard } \\
\text { Deviation }\end{array}$ & Minimum & Maximum & $\begin{array}{c}\text { Confidence Level } \\
\text { for mean (95\%) }\end{array}$ \\
\hline Population & 156.144 & 26.971 & 32 & 205 & 1.674 \\
\hline Number of cases & 94.292 & 11.547 & 32 & 112 & 0.717 \\
\hline Expected cases & 44.516 & 7.689 & 9.123 & 58.445 & 0.477 \\
\hline Estimated risk & 2.145 & 0.167 & 1.901 & 3.508 & 0.010 \\
\hline Relative risk & 2.774 & 0.129 & 2.544 & 3.904 & 0.008 \\
\hline P-value & $1.08 \mathrm{E}-11$ & $2.21 \mathrm{E}-11$ & $6.99 \mathrm{E}-15$ & $2.26 \mathrm{E}-10$ & $1.37 \mathrm{E}-12$ \\
\hline
\end{tabular}

Fig. 11. Map of the residence halls in the detected clusters from simulated space-time point patterns (number of simulations: 1,000)

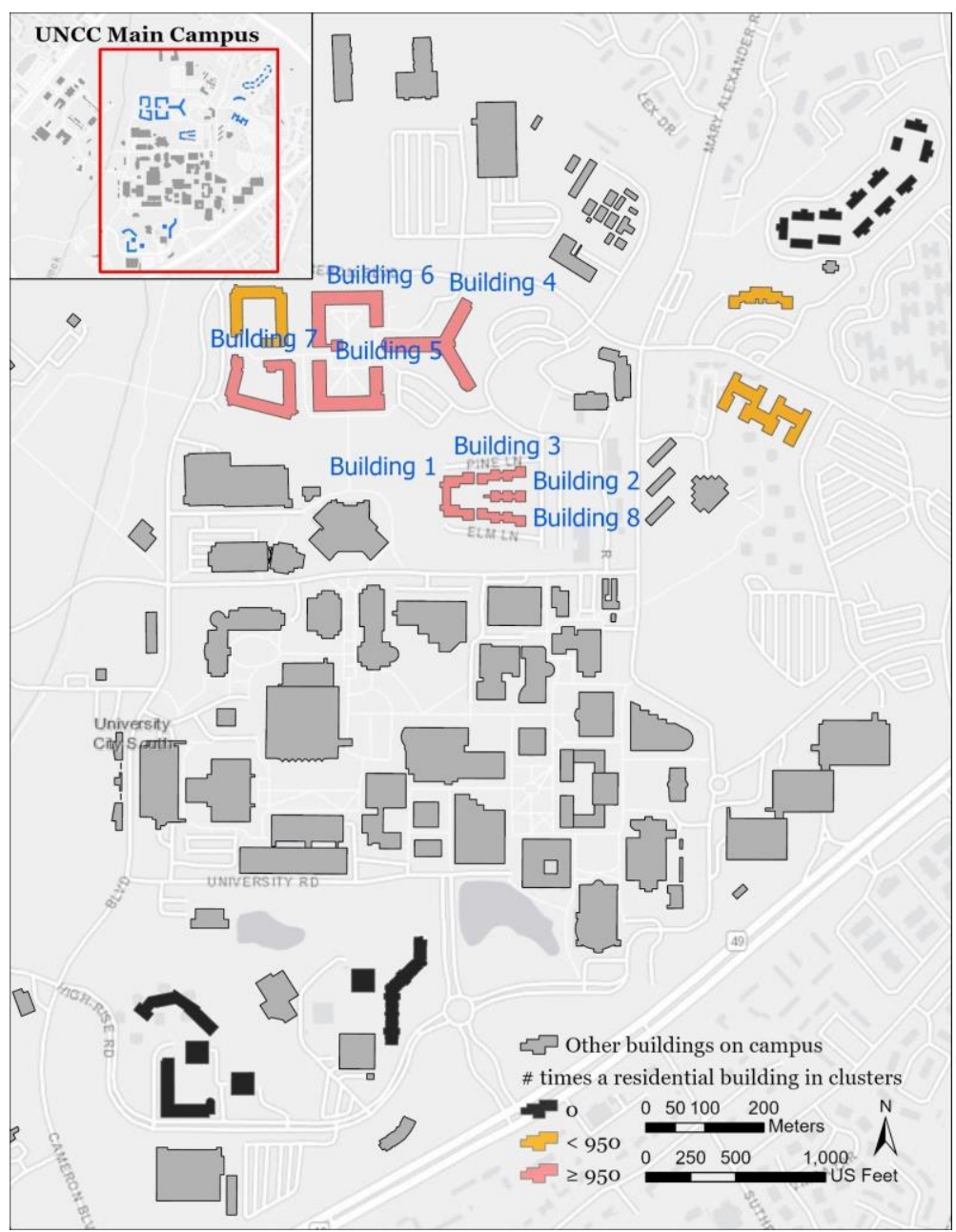

572 
medRxiv preprint doi: https://doi.org/10.1101/2021.12.29.21268516; this version posted January 1, 2022. The copyright holder for this preprint (which was not certified by peer review) is the author/funder, who has granted medRxiv a license to display the preprint in perpetuity.

It is made available under a CC-BY-NC-ND 4.0 International license.

574 Table 5. Start and end dates of the buildings detected within clusters based on 1,000 simulations.

\begin{tabular}{|c|c|c|c|}
\hline Building index & Start date $(\mathrm{p}<=0.05)$ & End date $(\mathrm{p}<=0.05)$ & Number of days at high risk \\
\hline Building 1 & $\operatorname{March} 23^{\text {rd }}, 2021$ & April $24^{\text {th }}, 2021$ & 33 \\
\hline Building 2 & $\operatorname{March} 23^{\text {rd }}, 2021$ & April $24^{\text {th }}, 2021$ & 33 \\
\hline Building 3 & $\operatorname{March} 23^{\text {rd }}, 2021$ & April $24^{\text {th }}, 2021$ & 33 \\
\hline Building 4 & $\operatorname{March} 23^{\text {rd }}, 2021$ & April $23^{\text {rd }}, 2021$ & 32 \\
\hline Building 5 & March $23^{\text {rd }}, 2021$ & April $23^{\text {rd }}, 2021$ & 32 \\
\hline Building 6 & $\operatorname{March} 23^{\text {rd }}, 2021$ & April $23^{\text {rd }}, 2021$ & 32 \\
\hline Building 7 & $\operatorname{March} 26^{\text {th }}, 2021$ & April $20^{\text {th }}, 2021$ & 26 \\
\hline Building 8 & $\operatorname{March} 23^{\text {rd }}, 2021$ & April $24^{\text {th }}, 2021$ & 33 \\
\hline
\end{tabular}

575

576 Table 6. Number of weeks covered by the space-time clusters detected from simulated patterns

577 (number of simulations: 1,000).

\begin{tabular}{c|c}
\hline \#Weeks & Frequency \\
\hline 1 week & 53 \\
\hline 2 weeks & 18 \\
\hline 3 weeks & 254 \\
\hline 4 weeks & 384 \\
\hline 5 weeks & 290 \\
\hline 6 weeks & 1 \\
\hline
\end{tabular}


medRxiv preprint doi: https://doi.org/10.1101/2021.12.29.21268516; this version posted January 1, 2022. The copyright holder for this preprint (which was not certified by peer review) is the author/funder, who has granted medRxiv a license to display the preprint in perpetuity.

It is made available under a CC-BY-NC-ND 4.0 International license .
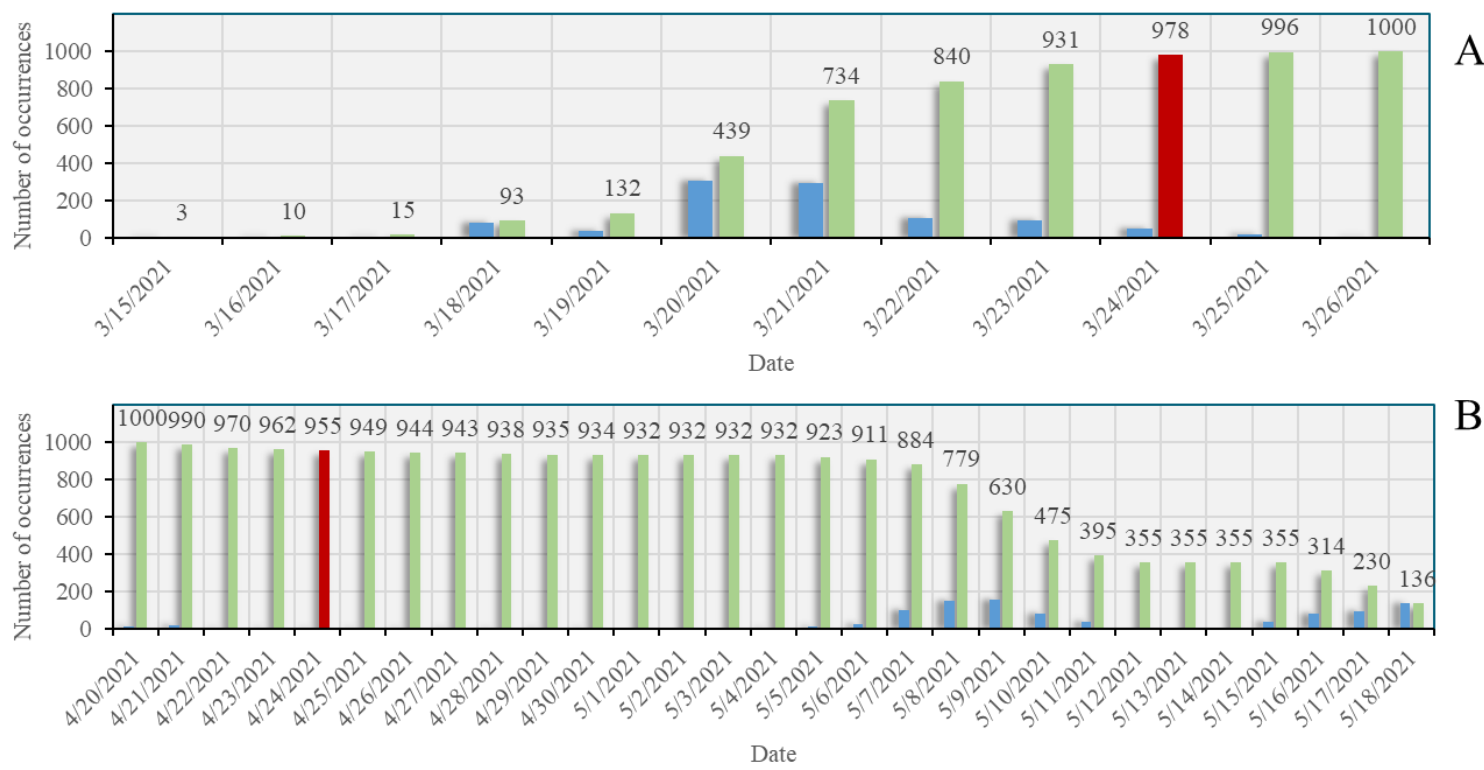

\section{B}

Fig. 12. Histograms of the start (A) and end (B) dates that a building (Building 1) was identified as within a cluster (blue) and the number of occurrences that a building was identified as within a cluster over time (green) from simulations. Significant start and end dates (95\% confidence level) were colored in red. Number of simulations: 1,000.

The use of space-time scan for cluster analysis is computationally demanding because each analysis would need additional 999 Monte Carlo runs for significance testing, and we need to conduct this analysis on 1,000 simulated space-time point patterns of presymptomatic individuals. To address this computational challenge, we deployed these analyses to a high performance computing (HPC) cluster (computing node configuration: dual 24-Core Intel Xeon Gold 6248R CPU with clock rate of $3.00 \mathrm{GHz}$ and 384GB memory). Twenty computing nodes (each with 24 cores--i.e., in total 480 CPUs) were used for acceleration. The parallel computing time of the analysis of a single simulated point pattern on a computing node varies from 7.76 to 16.26 minutes with a mean of 8.42 minutes, while the mean sequential computing time for a single analysis is 139.36 minutes. The total parallel computing time on 480 CPUs for 1,000 analyses is 7.08 hours, compared with the total sequential computing time (on a single CPU) of 
medRxiv preprint doi: https://doi.org/10.1101/2021.12.29.21268516; this version posted January 1, 2022. The copyright holder for this preprint (which was not certified by peer review) is the author/funder, who has granted medRxiv a license to display the preprint in perpetuity.

It is made available under a CC-BY-NC-ND 4.0 International license .

2,322.72 hours (around 97 days). As a result, 327.91 times of acceleration was achieved for these analyses by using 480 CPUs.

\subsection{Results of Similarity Analysis of Time Series}

We conducted similarity analyses based on the time series of wastewater testing results from the 23 sampling sites over the study period. Fig. 13 shows the results of similarity analysis with respect to metrics of Euclidean distance and DTW. Both Euclidean distance and DTW are dissimilarity metrics, meaning that the larger the value of the metrics, the more dissimilar the time series of two sites are. We then applied hierarchical clustering analysis to each of the two metrics. Elbow method (Thorndike, 1953) was used to determine the number of clusters based on these metrics. As a result, two clusters were identified with respect to the Euclidean distance metric and three clusters for the DTW metric.

Fig. 14 depicts the cluster dendrograms of the two similarity metrics as well as the spatial distribution of the identified clusters with respect to each of the similarity metrics. Fig. 15 shows the number of positive sites per week for each group identified by similarity metrics. The Euclidean distance-based metric clusters the sampling sites to two groups, whereas there are three main groups identified by the DTW metric. In terms of Euclidean distance-based metric (see Fig. 15A), group 1 covers five sampling sites, about $22 \%$ over 23 sampling sites in this study. The number of positive samples of group 1 fluctuates around 5 positive samples per collection day before and on March $15^{\text {th }}, 2021$. It rises to 10 - 15 positive samples per collection day from late March to mid April and then a decreasing trend appears until mid May. Group 2 has 18 sampling sites, around three times higher than those in group 1 . The number of positive 
medRxiv preprint doi: https://doi.org/10.1101/2021.12.29.21268516; this version posted January 1, 2022. The copyright holder for this preprint (which was not certified by peer review) is the author/funder, who has granted medRxiv a license to display the preprint in perpetuity.

It is made available under a CC-BY-NC-ND 4.0 International license .

samples for each group in the study period tends to be close compared with the total number of sampling sites in each group, indicating that buildings in group 1 are at higher risk of being exposed under virus than those in group 2 . We can also observe a rising pattern in the number of positive samples for group 2 in mid March and a decreasing trend from late April to the end of the study period.
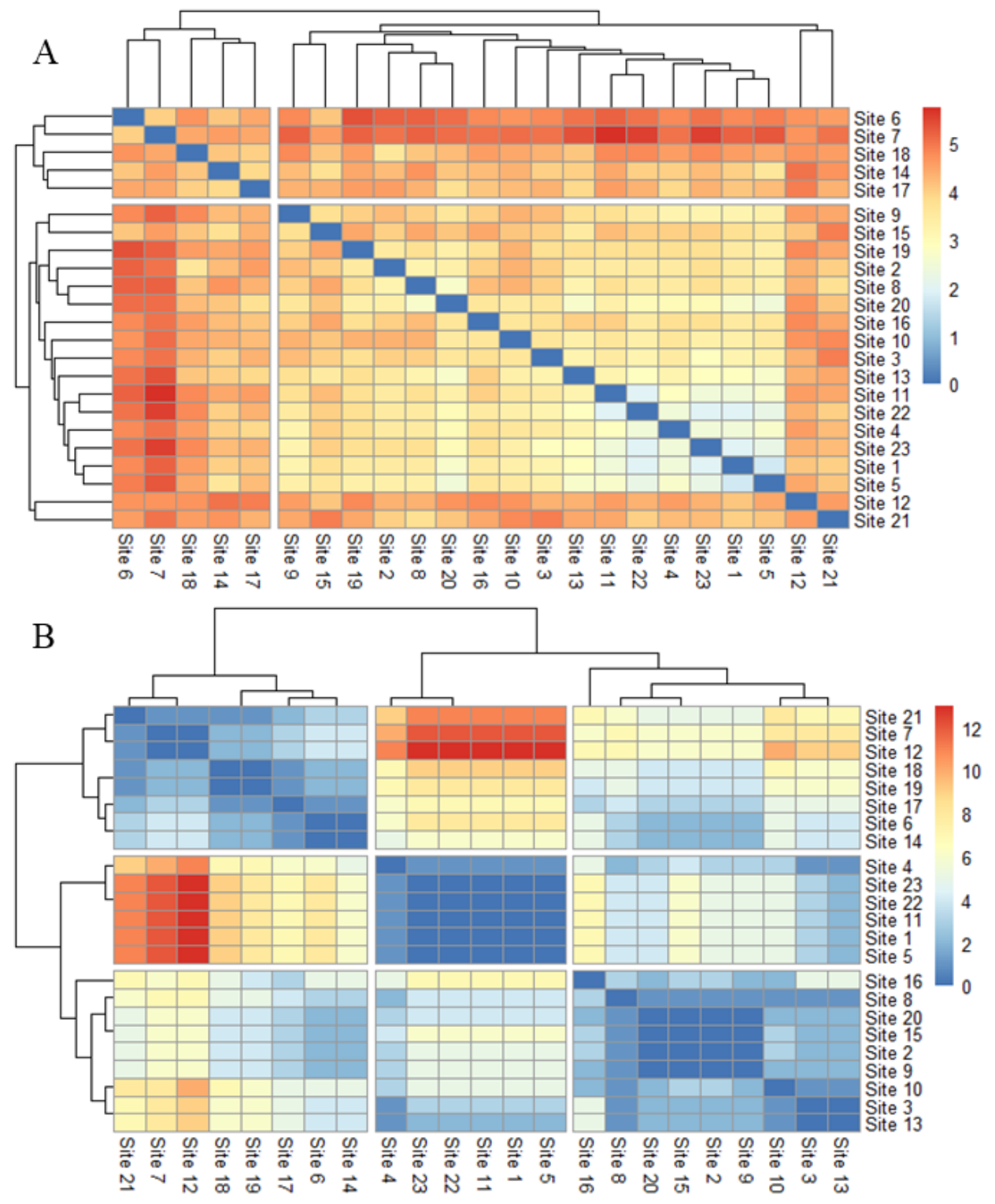

Fig. 13. Matrix of similarity metrics. (A: Euclidean distance; B: Dynamic Time Warping). 

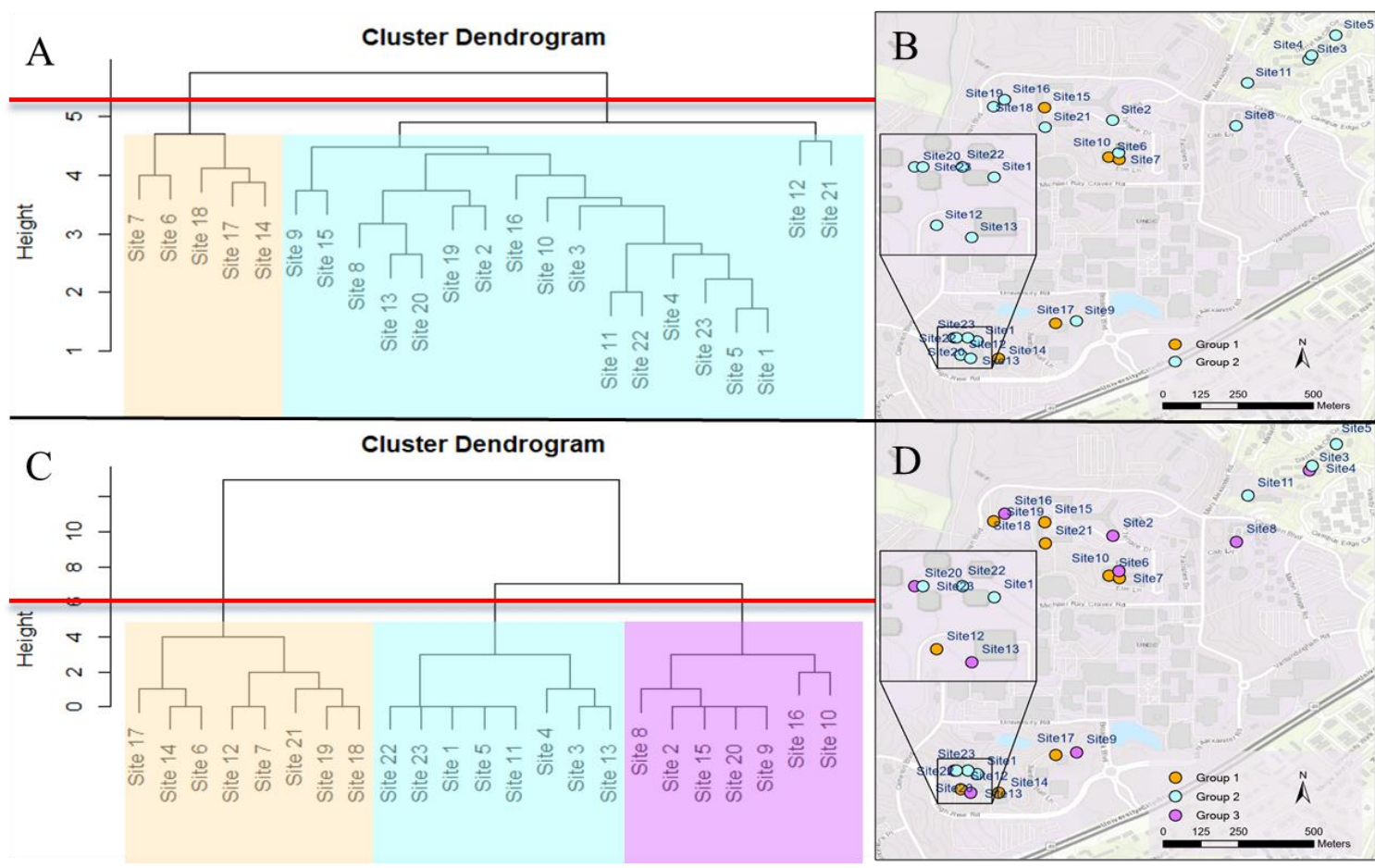

Fig. 14. Cluster dendrograms of similarity metrics and spatial patterns of clustered results. A and B are for Euclidean distance metric. C and D are for Dynamic Time Warping metric. The cut-off of the number of clusters (red line) was identified using the Elbow curves. Group 1, 2, and 3 were shaded in orange, blue, and purple. 
medRxiv preprint doi: https://doi.org/10.1101/2021.12.29.21268516; this version posted January 1, 2022. The copyright holder for this preprint (which was not certified by peer review) is the author/funder, who has granted medRxiv a license to display the preprint in perpetuity.

It is made available under a CC-BY-NC-ND 4.0 International license .
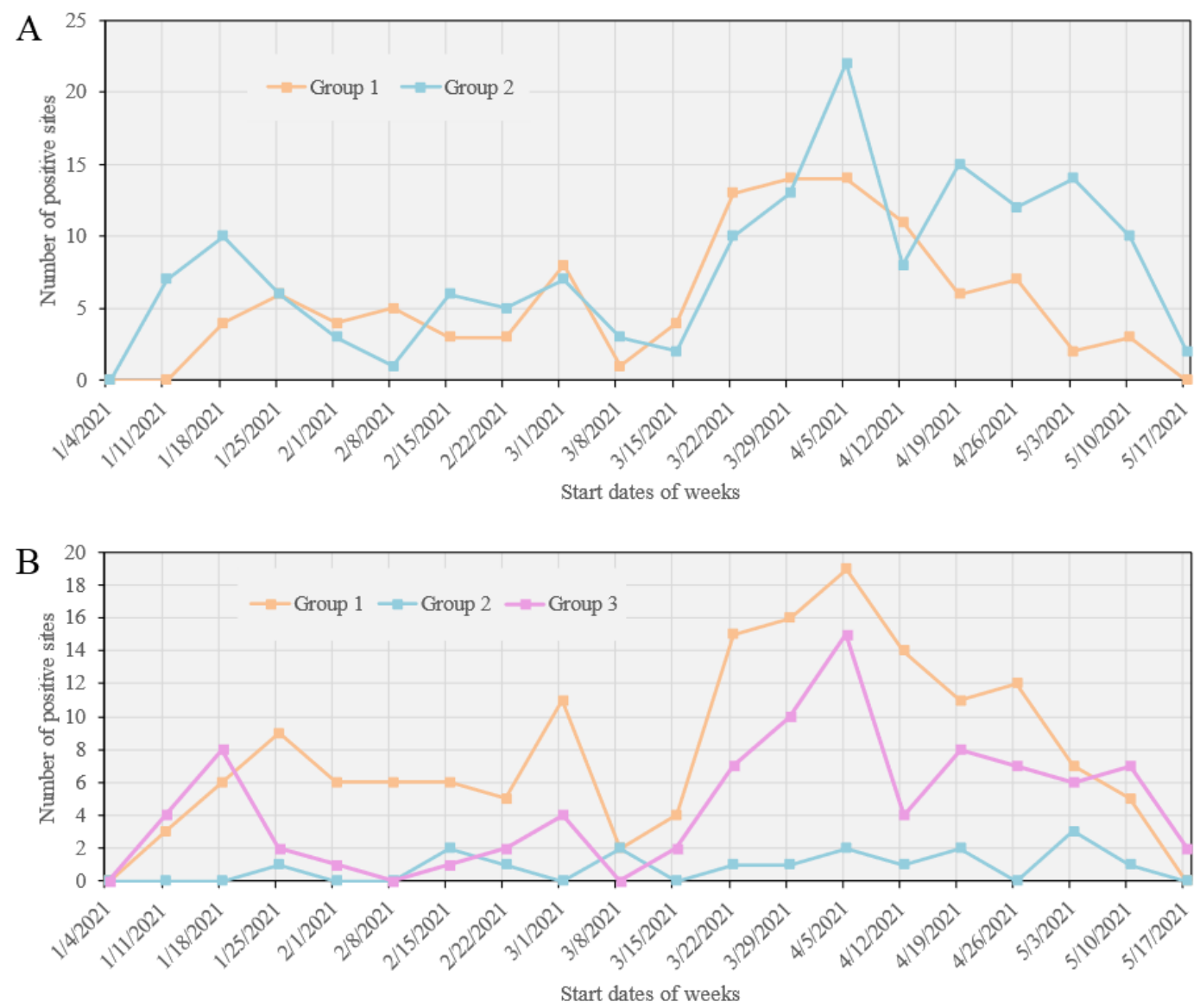

Fig. 15. Number of positive sampling sites per week for each group identified by similarity metric over time. A: for the Euclidean distance metric. B: for the Dynamic Time Warping metric. The horizontal axis shows the start date of each week. The last week starting from May $17^{\text {th }}$ only has two-days data available.

With respect to the DTW metric (see Fig. 15B), three groups are identified, where the number of sampling sites are 8, 6, and 9 for group 1,2, and 3. It is observed that the weekly number of positive samples in group 1 is higher than those of groups 2 and 3 in between January $25^{\text {th }}, 2021$ and May $3^{\text {rd }}, 2021$, covering most of the study period. The number of weekly positive samples in group 2 is higher than that in group 3 especially in the beginning of the study period until February $8^{\text {th }}, 2021$, and from March $15^{\text {th }}$ to May $18^{\text {th }}, 2021$. Group 3 stays between 0 to 3 positive samples per week during this time span. Group 1 and 2 exhibit similar responses to the 
medRxiv preprint doi: https://doi.org/10.1101/2021.12.29.21268516; this version posted January 1, 2022. The copyright holder for this preprint (which was not certified by peer review) is the author/funder, who has granted medRxiv a license to display the preprint in perpetuity.

It is made available under a CC-BY-NC-ND 4.0 International license .

645 spread of COVID-19 as we can observe three peaks in the time series: around January $20^{\text {th }}$,

646 March $1^{\text {st }}$, and April $5^{\text {th }}$. Both group 1 and 2 strongly responded to the wave in Mecklenburg

647 County, NC starting from mid March, 2021 (see Fig. 9); however, group 3 did not show a

648 significant reaction to this wave, indicating residence halls in this group appear a relatively lower

649 risk of being exposed to the virus than others during the study period.

650 Sites 6 and 7 identified in group 1 of both similarity metrics (see Fig. 14) are also detected within

651 the cluster using space-time scan (see Fig. 10), indicating that buildings related to the two sites

652 are more likely to be under exposure of the COVID-19 during the study period. Site 14,17 , and

65318 in group 1 for Euclidean distance are also included in the group 1 of DTW metric, indicating

654 these sites also need to be paid attention. Further, group 1 of DTW metric suggests that site 12,

65519 , and 21 are at relatively higher risk as well. Buildings in group 2 of the Euclidean distance

656 metric appear less likely to be under exposure of the virus than those in group 1. It can be

657 observed that buildings in group 2 and 3 detected by the DTW metric are included in group 2 of

658 the Euclidean distance. Results in Fig. 15B also suggests that the two groups of DTW metric,

659 especially group 2, appear to be characterized by a relatively low number of positive wastewater 660 samples during the study period.

661 5. Discussion

662 Our web-based SDSS provides support for automating data operations, analysis and modeling, 663 and visualization capabilities within an integrative environment. Wastewater surveillance is 664 dependent on various data that may cut across different spatiotemporal scales. Our web-based 665 SDSS allows for automated synchronization and mapping of these spatiotemporal data. This 
medRxiv preprint doi: https://doi.org/10.1101/2021.12.29.21268516; this version posted January 1, 2022. The copyright holder for this preprint (which was not certified by peer review) is the author/funder, who has granted medRxiv a license to display the preprint in perpetuity.

It is made available under a CC-BY-NC-ND 4.0 International license .

666

667

668

669

670

671

672 functioning of samplers.

673 Wastewater surveillance data are spatiotemporally explicit. Spatiotemporal analysis and

674

675

676

677

678

679

680

681

682

683

684

685

686

687

provides timely support for the early detection of the COVID-19 virus in campus wastewater and thus greatly facilitates the monitoring and mitigation of the pandemic situation in the University. At the same time, the management of space-time wastewater data within this integrated environment can help monitor the status of samplers and their sampling sites. If any issues occur to the autosamplers that lead to the unavailability of samples over time, we could quickly identify and resolve the issues with support from this SDSS, thus ensuring the continual modeling can be of great help in discovering interesting patterns in these spatiotemporal data, represented by the clusters of positive samples or residence halls detected using space-time scan approach and similarity analysis of space-time series in this study. The combination of the spatiotemporal analysis approaches has been suggested in the literature (see Xu \& Beard, 2021). Space-time scan methods, represented by SatScan in this study, allows for detecting the cooccurrence of space-time events (positive samples in this study) within a specific time period (i.e., local- or regional-level analysis). Further, similarity analysis of space-time series offers a means of comparing space-time events over the entire study period--i.e., system-level comparison. Combining these spatiotemporal analysis methods enables us to discover patterns of interest from different levels (with respect to the study system of interest). On the one hand, this combined approach allows for identifying those residence halls where interactions with their residents are at a high risk during specific time periods. On the other hand, it gives us recommendations on the group of residence halls with a lower risk of virus even when it was peaking. This combined analysis approach provides substantial support for addressing 
medRxiv preprint doi: https://doi.org/10.1101/2021.12.29.21268516; this version posted January 1, 2022. The copyright holder for this preprint (which was not certified by peer review) is the author/funder, who has granted medRxiv a license to display the preprint in perpetuity.

It is made available under a CC-BY-NC-ND 4.0 International license .

688

689

690

691

692

693

694

695

696

697

698

699

700

701

702

703

704

705

706

707

708

709

spatiotemporal questions (as in the Introduction section). It is also noted that the detection of these space-time clusters may be biased as samples may not be collected from every site each time, which will be investigated in future work. However, in general, these detected clusters from spatiotemporal analysis and modeling provide invaluable and critical support for the University on decisions or guidelines for the prevention of outbreak of the virus and control of virus transmission on campus.

The use of the space-time simulation of presymptomatic individuals was necessary because the relationship between sampling sites and their associated buildings is complicated (instead of oneto-one mapping) and because individuals in residence halls are sources that contribute to the wastewater testing results instead of samplers at sampling sites. The space-time scan results based on simulated individuals in residence halls are different than those based on sampling sites. The former approach detects more residence halls within the clusters of positive wastewater samples. The space-time simulation of the presymptomatic individuals provides an alternative approach for the possible locations of these individuals instead of relying on the sampling sites. While the detected clusters include more residence halls from space-time simulation, it is better than underestimating the number of residence halls that may exhibit strong positive signals of COVID-19 virus in wastewater. Of course, these clusters of positive wastewater samples are based on the space-time scan, which is a statistically based exploratory data analysis approach. The further interpretation of these clusters would require the expert knowledge from the collaboration of domain scientists (e.g., biogenetic professionals), better understanding of the wastewater surveillance system (e.g., sampling sites, residence halls, student interactions), and the incorporation of clinical testing and contact tracing data. In 
medRxiv preprint doi: https://doi.org/10.1101/2021.12.29.21268516; this version posted January 1, 2022. The copyright holder for this preprint (which was not certified by peer review) is the author/funder, who has granted medRxiv a license to display the preprint in perpetuity.

It is made available under a CC-BY-NC-ND 4.0 International license .

710 particular, clinical testing data could be used to further improve the space-time simulation of

711 presymptomatic individuals in terms of model calibration and validation. For example, in this

712 study, wastewater samples that have 2 or less replicates producing signals are treated as negative.

713 The use of clinical testing data could help us to fine tune the relationship between wastewater

714 signals and infected individuals for more reliable spatiotemporal cluster analysis.

715 Web-based GIS is of essence in this web-based SDSS in terms of visual presentation of space-

716 time data related to wastewater surveillance. Web-based GIS technologies and geospatial web

717 services have been increasingly developed and available for the online management and mapping

718 of spatially explicit data. However, the automatic update of data to Web GIS dashboards has

719 been the bottleneck of Web GIS applications. Our web-based GIS and visualization module

720 provides automation support that allows for the automatic update of wastewater sample data to

721 the web GIS dashboard. Specifically, we aimed to reduce the time and number of steps that data

722 are taken from the lab to the dashboard. This module will lead to the saving of tremendous time

723 and cost as required by the update and dissemination of wastewater data that are continuously

724 available over time.

\section{6. Conclusions}

726 The web-based SDSS framework presented in this study empowers the management, analytics

727 and sharing of wastewater surveillance-related data at multiple spatiotemporal scales. The SDSS

728 framework serves as a synergistic platform that integrates various types of data based on the

729 spatiotemporal data model. Spatiotemporal analysis and modeling capabilities incorporated in

730 this framework offer a means of unveiling interesting or unexpected patterns from the 
medRxiv preprint doi: https://doi.org/10.1101/2021.12.29.21268516; this version posted January 1, 2022. The copyright holder for this preprint (which was not certified by peer review) is the author/funder, who has granted medRxiv a license to display the preprint in perpetuity.

It is made available under a CC-BY-NC-ND 4.0 International license .

731 wastewater data. These patterns may not be easily detected using visual inspection. These data-

732 and model-related capabilities are managed and automated within the SDSS framework to ensure

733 their reusability and the reproducibility of analytic results. This SDSS framework, built in with

734 Web GIS dashboard functionality, will inform critical decision-making and guideline

735 development for monitoring COVID-19 situations in the study region.

736 Future work of our study includes: 1) integration of 3D BIM-based building model into the web-

737 based environment, 2) adding more spatial modeling capabilities (e.g., spatial simulation for

738 scenario analysis and representation of individual behavior and social behavior using agent-

739 based modeling; spatial optimization for optimal allocation of sampling sites), 3) use of

740 continuous variable of virus concentration in wastewater samples instead of binary indicator for

741 spatiotemporal analysis, and 4) extend the web-based SDSS framework to other or larger regions

742 by, for example, linking to city sewage network and wastewater treatment plants at regional

743 level. 
medRxiv preprint doi: https://doi.org/10.1101/2021.12.29.21268516; this version posted January 1, 2022. The copyright holder for this preprint (which was not certified by peer review) is the author/funder, who has granted medRxiv a license to display the preprint in perpetuity.

It is made available under a CC-BY-NC-ND 4.0 International license.

\section{Acknowledgements}

745 The authors would like to thank Chancellor Sharon Gaber, Provost Joan Lorden, and Richard

746 Tankersley, Vice Chancellor for Research and Economic Development and his team for strong

747 institutional support of this wastewater surveillance project, Deborah Thomas, Chair of the

748 Department of Geography and Earth Sciences for facilitating setting up geospatial computing

749 needs for the project. The authors owe thanks to Facilities Management (Greg Cole) and OneIT

750 (Alex Chapin, Elie Saliba) at the University of North Carolina at Charlotte for their support and

751 help on sampling site setup and computing needs. High-performance computing resources used

752 in this project were provided by University Research Computing at the University of North

753 Carolina at Charlotte.

754

755 Funding:

756 The authors would like to thank financial support through CARES funding from NC General

757 Assembly and funding from the University of North Carolina at Charlotte. 
medRxiv preprint doi: https://doi.org/10.1101/2021.12.29.21268516; this version posted January 1, 2022. The copyright holder for this preprint (which was not certified by peer review) is the author/funder, who has granted medRxiv a license to display the preprint in perpetuity.

It is made available under a CC-BY-NC-ND 4.0 International license .

\section{References}

Aghabozorgi, S., Shirkhorshidi, A. S., \& Wah, T. Y. (2015). Time-series clustering-a decade review. Information Systems, 53, 16-38. https://doi.org/10.1016/j.is.2015.04.007

Ahmed, W., Tscharke, B., Bertsch, P. M., Bibby, K., Bivins, A., Choi, P., Clarke, L., Dwyer, J., Edson, J., Nguyen, T. M. H., O’Brien, J. W., Simpson, S. L., Sherman, P., Thomas, K. V., Verhagen, R., Zaugg, J., \& Mueller, J. F. (2021). SARS-CoV-2 RNA monitoring in wastewater as a potential early warning system for COVID-19 transmission in the community: A temporal case study. The Science of the Total Environment, 761, 144216. https://doi.org/10.1016/j.scitotenv.2020.144216

Armstrong, M. P., Densham, P. J., \& Rushton, G. (1986). Architecture for a microcomputer based spatial decision support system. Second International Symposium on Spatial Data Handling, International Geographic Union, 120-131. https://iro.uiowa.edu/esploro/outputs/conferenceProceeding/Architecture-for-amicrocomputer-based-spatial/9983557551002771

Barua, V. B., Juel, M. A. I., Blackwood, A. D., Clerkin, T., Ciesielski, M., Sorinolu, A. J., Holcomb, D. A., Young, I., Kimble, G., Sypolt, S., Engel, L. S., Noble, R. T., \& Munir, M. (2021). Tracking the temporal variation of COVID-19 surges through wastewater-based epidemiology during the peak of the pandemic: A six-month long study in Charlotte, North Carolina. The Science of the Total Environment, 152503. https://doi.org/10.1016/j.scitotenv.2021.152503

Becerik-Gerber, B., Jazizadeh, F., Li, N., \& Calis, G. (2012). Application Areas and Data Requirements for BIM-Enabled Facilities Management. Journal of Construction 
medRxiv preprint doi: https://doi.org/10.1101/2021.12.29.21268516; this version posted January 1, 2022. The copyright holder for this preprint (which was not certified by peer review) is the author/funder, who has granted medRxiv a license to display the preprint in perpetuity.

It is made available under a CC-BY-NC-ND 4.0 International license .

Engineering and Management, 138(3), 431-442. https://doi.org/10.1061/(ASCE)CO.19437862.0000433

Berndt, D. J., \& Clifford, J. (1994). Using dynamic time warping to find patterns in time series. KDD Workshop, 10, 359-370. https://www.aaai.org/Library/Workshops/1994/ws94-03031.php

Bowes, D. A., Driver, E. M., Kraberger, S., Fontenele, R. S., Holland, L. A., Wright, J., Johnston, B., Savic, S., Newell, M. E., \& Adhikari, S. (2021). Unrestricted Online Sharing of High-frequency, High-resolution Data on SARS-CoV-2 in Wastewater to Inform the COVID-19 Public Health Response in Greater Tempe, Arizona. medRxiv. https://doi.org/10.1101/2021.07.29.21261338

Chen, B. Y., Yuan, H., Li, Q., Shaw, S.-L., Lam, W. H. K., \& Chen, X. (2016). Spatiotemporal data model for network time geographic analysis in the era of big data. International Journal of Geographical Information Science, 30(6), 1041-1071. https://doi.org/10.1080/13658816.2015.1104317

Choi, S. S., Cha, S. H., \& Tappert, C. C. (2010). A survey of binary similarity and distance measures. Journal of Systemics, Cybernetics and Informatics, 8(1), 43-48. http://citeseerx.ist.psu.edu/viewdoc/download?doi=10.1.1.352.6123\&rep=rep1\&type=pdf Ciesielski, M., Blackwood, D., Clerkin, T., Gonzalez, R., Thompson, H., Larson, A., \& Noble, R. (2021). Assessing sensitivity and reproducibility of RT-ddPCR and RT-qPCR for the quantification of SARS-CoV-2 in wastewater. Journal of Virological Methods, 297, 114230. https://doi.org/10.1016/j.jviromet.2021.114230

Crimi, A., Jones, T., \& Sgalambro, A. (2019). Designing a Web Spatial Decision Support 
medRxiv preprint doi: https://doi.org/10.1101/2021.12.29.21268516; this version posted January 1, 2022. The copyright holder for this preprint (which was not certified by peer review) is the author/funder, who has granted medRxiv a license to display the preprint in perpetuity.

It is made available under a CC-BY-NC-ND 4.0 International license .

System Based on Analytic Network Process to Locate a Freight Lorry Parking.

Sustainability: Science Practice and Policy, 11(20), 5629.

https://doi.org/10.3390/su11205629

Delmelle, E., Zhu, H., Tang, W., \& Casas, I. (2014). A web-based geospatial toolkit for the monitoring of dengue fever. Applied Geography , 52, 144-152. https://doi.org/10.1016/j.apgeog.2014.05.007

Densham, P. J. (1991). Spatial decision support systems. In D. J. Maguire, M. F. Goodchild, \& D. W. Rhind (Eds.), Geographical Information Systems: Principles and Applications (Vol. 1, pp. 403-412). Hoboken, NJ: John Wiley \& Sons.

Desjardins, M. R., Hohl, A., \& Delmelle, E. (2020). Rapid surveillance of COVID-19 in the United States using a prospective space-time scan statistic: Detecting and evaluating emerging clusters. Applied Geography, 118, 102202. https://doi.org/10.1016/j.apgeog.2020.102202

Diggle, P. J. (2013). Statistical Analysis of Spatial and Spatio-Temporal Point Patterns, Third Edition. CRC Press.

Dong, E., Du, H., \& Gardner, L. (2020). An interactive web-based dashboard to track COVID-19 in real time. The Lancet Infectious Diseases, 20(5), 533-534. https://doi.org/10.1016/S1473-3099(20)30120-1

Fox, M. D., Bailey, D. C., Seamon, M. D., \& Miranda, M. L. (2021). Response to a COVID-19 outbreak on a University Campus_-Indiana, August 2020. Morbidity and Mortality Weekly Report, 70(4), 118. https://doi.org/10.15585/mmwr.mm7004a3

Franch-Pardo, I., Napoletano, B. M., Rosete-Verges, F., \& Billa, L. (2020). Spatial analysis and 
medRxiv preprint doi: https://doi.org/10.1101/2021.12.29.21268516; this version posted January 1, 2022. The copyright holder for this preprint (which was not certified by peer review) is the author/funder, who has granted medRxiv a license to display the preprint in perpetuity.

It is made available under a CC-BY-NC-ND 4.0 International license .

GIS in the study of COVID-19. A review. The Science of the Total Environment, 739, 140033. https://doi.org/10.1016/j.scitotenv.2020.140033

Fu, P., \& Sun, J. (2011). Web GIS: Principles and Applications. Redlands, CA: Esri Press.

Ghosh, D. (2008). A loose coupling technique for integrating GIS and multi-criteria decision making. Transactions in GIS, 12(3), 365-375. https://doi.org/10.1111/j.14679671.2008.01103.x

Gibas, C., Lambirth, K., Mittal, N., Juel, M. A. I., Barua, V. B., Roppolo Brazell, L., Hinton, K., Lontai, J., Stark, N., Young, I., Quach, C., Russ, M., Kauer, J., Nicolosi, B., Chen, D., Akella, S., Tang, W., Schlueter, J., \& Munir, M. (2021). Implementing building-level SARS-CoV-2 wastewater surveillance on a university campus. The Science of the Total Environment, 782, 146749. https://doi.org/10.1016/j.scitotenv.2021.146749

Harris-Lovett, S., Nelson, K. L., Beamer, P., Bischel, H. N., Bivins, A., Bruder, A., Butler, C., Camenisch, T. D., De Long, S. K., Karthikeyan, S., Larsen, D. A., Meierdiercks, K., Mouser, P. J., Pagsuyoin, S., Prasek, S. M., Radniecki, T. S., Ram, J. L., Roper, D. K., Safford, H., ... Korfmacher, K. S. (2021). Wastewater Surveillance for SARS-CoV-2 on College Campuses: Initial Efforts, Lessons Learned, and Research Needs. International Journal of Environmental Research and Public Health, 18(9), 4455. https://doi.org/10.3390/ijerph18094455

Hohl, A., Delmelle, E., Desjardins, M. R., \& Lan, Y. (2020). Daily surveillance of COVID-19 using the prospective space-time scan statistic in the United States. Spatial and SpatioTemporal Epidemiology, 34, 100354. https://doi.org/10.1016/j.sste.2020.100354

Juel, M. A. I., Stark, N., Nicolosi, B., Lontai, J., Lambirth, K., Schlueter, J., Gibas, C., \& Munir, 
medRxiv preprint doi: https://doi.org/10.1101/2021.12.29.21268516; this version posted January 1, 2022. The copyright holder for this preprint (which was not certified by peer review) is the author/funder, who has granted medRxiv a license to display the preprint in perpetuity.

It is made available under a CC-BY-NC-ND 4.0 International license .

M. (2021). Performance evaluation of virus concentration methods for implementing SARS-CoV-2 wastewater based epidemiology emphasizing quick data turnaround. The Science of the Total Environment, 801, 149656. https://doi.org/10.1016/j.scitotenv.2021.149656

Karthikeyan, S., Nguyen, A., McDonald, D., Zong, Y., Ronquillo, N., Ren, J., Zou, J., Farmer, S., Humphrey, G., Henderson, D., Javidi, T., Messer, K., Anderson, C., Schooley, R., Martin, N. K., \& Knight, R. (2021). Rapid, Large-Scale Wastewater Surveillance and Automated Reporting System Enable Early Detection of Nearly 85\% of COVID-19 Cases on a University Campus. mSystems. https://doi.org/10.1128/mSystems.00793-21

Keenan, P. B., \& Jankowski, P. (2019). Spatial Decision Support Systems: Three decades on. Decision Support Systems, 116, 64-76. https://doi.org/10.1016/j.dss.2018.10.010

Kim, S., \& Castro, M. C. (2020). Spatiotemporal pattern of COVID-19 and government response in South Korea (as of May 31, 2020). International Journal of Infectious Diseases, 98, 328333. https://doi.org/10.1016/j.ijid.2020.07.004

Kırbıyık, U., Binder, A. M., Ghinai, I., \& Zawitz, C. (2020). Network Characteristics and Visualization of COVID-19 Outbreak in a Large Detention Facility in the United StatesCook County, Illinois, 2020. Morbidity and Mortality Weekly Report. Surveillance Summaries , 69(44), 1625. https://doi.org/10.15585/mmwr.mm6944a3

Kulldorff, M. (1997). A spatial scan statistic. Communications in Statistics: Theory and Methods, 26(6), 1481-1496. https://doi.org/10.1080/03610929708831995

Kulldorff, M. (1999). Spatial scan statistics: Models, calculations, and applications. In Scan Statistics and Applications (pp. 303-322). Birkhäuser Boston. https://doi.org/10.1007/978- 
medRxiv preprint doi: https://doi.org/10.1101/2021.12.29.21268516; this version posted January 1, 2022. The copyright holder for this preprint (which was not certified by peer review) is the author/funder, who has granted medRxiv a license to display the preprint in perpetuity.

It is made available under a CC-BY-NC-ND 4.0 International license .

\section{1-4612-1578-3_14}

Kulldorff, M., Athas, W. F., Feurer, E. J., Miller, B. A., \& Key, C. R. (1998). Evaluating cluster alarms: a space-time scan statistic and brain cancer in Los Alamos, New Mexico. American Journal of Public Health, 88(9), 1377-1380. https://doi.org/10.2105/ajph.88.9.1377

Lam-Hine, T., McCurdy, S. A., Santora, L., Duncan, L., Corbett-Detig, R., Kapusinszky, B., \& Willis, M. (2021). Outbreak associated with SARS-CoV-2 B. 1.617. 2 (delta) variant in an elementary school-Marin County, California, May-June 2021. Morbidity and Mortality Weekly Report. Surveillance Summaries, 70(35), 1214. https://doi.org/10.15585/mmwr.mm7035e2

Lan, Y., Desjardins, M. R., Hohl, A., \& Delmelle, E. (2021). Geovisualization of COVID-19: State of the art and opportunities. Cartographica The International Journal for Geographic Information and Geovisualization, 56(1), 2-13. https://doi.org/10.3138/cart-2020-0027

Lan, Y., Tang, W., Dye, S., \& Delmelle, E. (2020). A web-based spatial decision support system for monitoring the risk of water contamination in private wells. Annals of GIS, 26(3), 293309. https://doi.org/10.1080/19475683.2020.1798508

Lee, E. K., Pietz, F. H., Chen, C.-H., \& Liu, Y. (2017). An interactive web-based decision support system for mass dispensing, emergency preparedness, and biosurveillance. Proceedings of the 2017 International Conference on Digital Health, 137-146. https://doi.org/10.1145/3079452.3079473

Liu, P., Ibaraki, M., VanTassell, J., Geith, K., Cavallo, M., Kann, R., Guo, L., \& Moe, C. L. (2021). A sensitive, simple, and low-cost method for COVID-19 wastewater surveillance at an institutional level. The Science of the Total Environment, 151047. 
medRxiv preprint doi: https://doi.org/10.1101/2021.12.29.21268516; this version posted January 1, 2022. The copyright holder for this preprint (which was not certified by peer review) is the author/funder, who has granted medRxiv a license to display the preprint in perpetuity.

It is made available under a CC-BY-NC-ND 4.0 International license .

https://doi.org/10.1016/j.scitotenv.2021.151047

Malczewski, J. (1999). GIS and Multicriteria Decision Analysis. Hoboken, NJ: John Wiley \& Sons.

Marakas, G. M. (2003). Decision support systems in the 21st century (Vol. 134). Upper Saddle River, NJ: Prentice Hall.

Masrur, A., Yu, M., Luo, W., \& Dewan, A. (2020). Space-Time Patterns, Change, and Propagation of COVID-19 Risk Relative to the Intervention Scenarios in Bangladesh. International Journal of Environmental Research and Public Health, 17(16), 5911. https://doi.org/10.3390/ijerph17165911

Medema, G., Been, F., Heijnen, L., \& Petterson, S. (2020). Implementation of environmental surveillance for SARS-CoV-2 virus to support public health decisions: Opportunities and challenges. Current Opinion in Environmental Science \& Health, 17, 49-71. https://doi.org/10.1016/j.coesh.2020.09.006

Mwaura, D., \& Kada, M. (2017). Developing a web-based spatial decision support system for geothermal exploration at the Olkaria geothermal field. International Journal of Digital Earth, 10(11), 1118-1145. https://doi.org/10.1080/17538947.2017.1284909

Naughton, C. C., Roman, F. A., Alvarado, A. G. F., Tariqi, A. Q., Deeming, M. A., Bibby, K., Bivins, A., Rose, J. B., Medema, G., Ahmed, W., \& Others. (2021). Show us the data: Global COVID-19 wastewater monitoring efforts, equity, and gaps. medRxiv. https://doi.org/10.1101/2021.03.14.21253564

NC government. (2021a, February 24). Governor Cooper Announces Easing of COVID-19 Restrictions as North Carolina Trends Stabilize. https://governor.nc.gov/news/press- 
medRxiv preprint doi: https://doi.org/10.1101/2021.12.29.21268516; this version posted January 1, 2022. The copyright holder for this preprint (which was not certified by peer review) is the author/funder, who has granted medRxiv a license to display the preprint in perpetuity.

It is made available under a CC-BY-NC-ND 4.0 International license .

releases/2021/02/24/governor-cooper-announces-easing-covid-19-restrictions-northcarolina-trends-stabilize

NC government. (2021b, March 23). Gov. Cooper Announces North Carolina Will Relax Some COVID-19 Restrictions. https://governor.nc.gov/news/press-releases/2021/03/23/govcooper-announces-north-carolina-will-relax-some-covid-19-restrictions

NSF. (2007). Cyberinfrastructure Vision for 21st Century Discovery. National Science Foundation, Cyberinfrastructure Council. https://www.nsf.gov/pubs/2007/nsf0728/

Peccia, J., Zulli, A., Brackney, D. E., Grubaugh, N. D., Kaplan, E. H., Casanovas-Massana, A., Ko, A. I., Malik, A. A., Wang, D., Wang, M., Warren, J. L., Weinberger, D. M., Arnold, W., \& Omer, S. B. (2020). Measurement of SARS-CoV-2 RNA in wastewater tracks community infection dynamics. Nature Biotechnology, 38(10), 1164-1167. https://doi.org/10.1038/s41587-020-0684-z

Pelekis, N., Theodoulidis, B., Kopanakis, I., \& Theodoridis, Y. (2004). Literature review of spatio-temporal database models. Knowledge Engineering Review, 19(3), 235-274. https://doi.org/10.1017/s026988890400013x

Peng, Z.-R., \& Tsou, M.-H. (2003). Internet GIS: Distributed Geographic Information Services for the Internet and Wireless Networks. John Wiley \& Sons.

Peuquet, D. J., \& Duan, N. (1995). An event-based spatiotemporal data model (ESTDM) for temporal analysis of geographical data. International Journal of Geographical Information Systems, 9(1), 7-24. https://doi.org/10.1080/02693799508902022

Prado, T., Fumian, T. M., Miagostovich, M. P., \& Gaspar, A. M. C. (2012). Monitoring the hepatitis A virus in urban wastewater from Rio de Janeiro, Brazil. Transactions of the Royal 
medRxiv preprint doi: https://doi.org/10.1101/2021.12.29.21268516; this version posted January 1, 2022. The copyright holder for this preprint (which was not certified by peer review) is the author/funder, who has granted medRxiv a license to display the preprint in perpetuity.

It is made available under a CC-BY-NC-ND 4.0 International license .

Society of Tropical Medicine and Hygiene, 106(2), 104-109. https://doi.org/10.1016/j.trstmh.2011.10.005

Sakoe, H., \& Chiba, S. (1978). Dynamic programming algorithm optimization for spoken word recognition. IEEE Transactions on Acoustics, Speech, and Signal Processing, 26(1), 43-49. https://doi.org/10.1109/tassp.1978.1163055

Sugumaran, R., \& Degroote, J. (2010). Spatial Decision Support Systems: Principles and Practices. Boca Raton, FL: CRC Press.

Sweetapple, C., Melville-Shreeve, P., Chen, A. S., Grimsley, J. M., Bunce, J. T., Gaze, W., Fielding, S., \& Wade, M. J. (2022). Building knowledge of university campus population dynamics to enhance near-to-source sewage surveillance for SARS-CoV-2 detection. The Science of the Total Environment, 806, 150406. https://doi.org/10.1016/j.scitotenv.2021.150406

Tambini, G., Andrus, J. K., Marques, E., Boshell, J., Pallansch, M., de Quadros, C. A., \& Kew, O. (1993). Direct detection of wild poliovirus circulation by stool surveys of healthy children and analysis of community wastewater. The Journal of Infectious Diseases, 168(6), 1510-1514. https://doi.org/10.1093/infdis/168.6.1510

Tang, W., Feng, W., Jia, M., Shi, J., Zuo, H., Stringer, C. E., \& Trettin, C. C. (2017). A cyberenabled spatial decision support system to inventory Mangroves in Mozambique: coupling scientific workflows and cloud computing. International Journal of Geographical Information Science. https://doi.org/10.1080/13658816.2016.1245419

Tayyebi, A., Meehan, T. D., Dischler, J., Radloff, G., Ferris, M., \& Gratton, C. (2016). SmartScape ${ }^{\mathrm{TM}}$ : A web-based decision support system for assessing the tradeoffs among 
medRxiv preprint doi: https://doi.org/10.1101/2021.12.29.21268516; this version posted January 1, 2022. The copyright holder for this preprint (which was not certified by peer review) is the author/funder, who has granted medRxiv a license to display the preprint in perpetuity. It is made available under a CC-BY-NC-ND 4.0 International license.

multiple ecosystem services under crop-change scenarios. Computers and Electronics in

957 Agriculture, 121, 108-121. https://doi.org/10.1016/j.compag.2015.12.003

958 Thorndike, R. L. (1953). Who belongs in the family? Psychometrika, 18(4), 267-276.

959 https://doi.org/10.1007/BF02289263

$960 \mathrm{Xu}, \mathrm{F} .$, \& Beard, K. (2021). A comparison of prospective space-time scan statistics and 961 spatiotemporal event sequence based clustering for COVID-19 surveillance. PloS One, 16(6), e0252990. https://doi.org/10.1371/journal.pone.0252990 


\section{Appendix}

965 Appendix 1. Sources of the information about the University of North Carolina at Charlotte 966 (retrieved year: 2021).

\begin{tabular}{|l|l|}
\hline Sources & URLs \\
\hline Faculty and Staff Resources & https://www.charlotte.edu/gateway/faculty-staff \\
\hline Housing and Residence Life & https://housing.charlotte.edu/ \\
\hline University Catalogs & $\begin{array}{l}\text { https://catalog.uncc.edu/preview_program.php?catoi } \\
\text { d=30\&poid=8179 }\end{array}$ \\
\hline Housing and Residence Life & $\begin{array}{l}\text { https://housing.charlotte.edu/housing-options/find- } \\
\text { your-home }\end{array}$ \\
\hline Undergraduate Admissions & $\begin{array}{l}\text { https://admissions.charlotte.edu/about-unc- } \\
\text { charlotte/university-profile }\end{array}$ \\
\hline
\end{tabular}

